\title{
Particulate matter pollution over China and the effects of control policies
}

\section{Wang, Jiandong}

2017-04-15

Wang , J , Zhao , B , Wang , S , Yang , F , Xing , J , Morawska , L, Ding , A, Kulmala , M , Kerminen, V-M , Kujansuu , J , Wang , Z, Ding, D , Zhang, X, Wang , H, Tian, M , Petäjä , T , Jiang , J \& Hao , J 2017 , ' Particulate matter pollution over China and the effects of control policies ' , The Science of the Total Environment , vol. 584 , pp. 426-447 . https://doi.org/10.1016/j.scitotenv.2

http://hdl.handle.net/10138/313041

https://doi.org/10.1016/j.scitotenv.2017.01.027

cc_by_nc_nd

acceptedVersion

Downloaded from Helda, University of Helsinki institutional repository.

This is an electronic reprint of the original article.

This reprint may differ from the original in pagination and typographic detail.

Please cite the original version. 


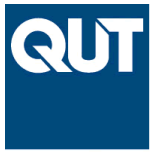

Queensland University of Technology

Brisbane Australia

This may be the author's version of a work that was submitted/accepted for publication in the following source:

Wang, Jiandong, Zhao, Bin, Wang, Shuxiao, Yang, Fumo, Xing, Jia, Morawska, Lidia, \& other, and

(2017)

Particulate matter pollution over China and the effects of control policies.

Science of the Total Environment, 584 - 585, pp. 426-447.

This file was downloaded from: https://eprints.qut.edu.au/107849/

\section{(C) Consult author(s) regarding copyright matters}

This work is covered by copyright. Unless the document is being made available under a Creative Commons Licence, you must assume that re-use is limited to personal use and that permission from the copyright owner must be obtained for all other uses. If the document is available under a Creative Commons License (or other specified license) then refer to the Licence for details of permitted re-use. It is a condition of access that users recognise and abide by the legal requirements associated with these rights. If you believe that this work infringes copyright please provide details by email to qut.copyright@qut.edu.au

Notice: Please note that this document may not be the Version of Record (i.e. published version) of the work. Author manuscript versions (as Submitted for peer review or as Accepted for publication after peer review) can be identified by an absence of publisher branding and/or typeset appearance. If there is any doubt, please refer to the published source.

https://doi.org/10.1016/j.scitotenv.2017.01.027 


\section{Particulate matter pollution over China and the effects of control}

\section{measures}

Jiandong Wang ${ }^{\mathrm{a}, \mathrm{b}}$, Bin Zhao ${ }^{\mathrm{c}}$, Shuxiao Wang ${ }^{\mathrm{a}, \mathrm{b} *}$, Fumo Yang ${ }^{\mathrm{d}, \mathrm{e} *}$, Jia Xing ${ }^{\mathrm{a}, \mathrm{b}}$, Lidia Morawska ${ }^{\mathrm{f}}$, Aijun Ding ${ }^{g}$, Markku Kulmala ${ }^{\text {h}}$, Veli-Matti Kerminen ${ }^{\text {h}}$, Joni Kujansuu ${ }^{\text {h, }}$ Zifa Wang ${ }^{\text {i, }}$, Dian Ding ${ }^{\text {a, b }}$, Xiaoye Zhang ${ }^{j}$, Huanbo Wang d, Mi Tian ${ }^{d}$, Tuukka Petäjä ${ }^{\text {h }}$, Jingkun Jiang a, b, Jiming Hao ${ }^{\text {a, b }}$

${ }^{\text {a }}$ State Key Joint Laboratory of Environment Simulation and Pollution Control, School of Environment, Tsinghua University, Beijing 100084, China

${ }^{\mathrm{b}}$ State Environmental Protection Key Laboratory of Sources and Control of Air Pollution Complex, Beijing 100084, China

${ }^{\mathrm{c}}$ Joint Institute for Regional Earth System Science and Engineering and Department of Atmospheric and Oceanic Sciences, University of California, Los Angeles, CA 90095, USA

${ }^{\mathrm{d}}$ Chongqing Institute of Green and Intelligent Technology, Chinese Academy of Sciences, Chongqing, 400714, China

${ }^{\mathrm{e}}$ Center for Excellence in Urban Atmospheric Environment, Institute of Urban Environment, Chinese Academy of Sciences, Xiamen, 361021, China

${ }^{\mathrm{f}}$ International Laboratory for Air Quality and Health, Queensland University of Technology, GPO Box 2434, Brisbane QLD, 44001, Australia

g Joint International Research Laboratory of Atmospheric and Earth System Sciences, School of Atmospheric Sciences, Nanjing University, 210023, Nanjing China

${ }^{\mathrm{h}}$ Department of Physics, University of Helsinki, 00014 Helsinki, Finland

${ }^{i}$ State Key Laboratory of Atmospheric Boundary Layer Physics and Atmospheric Chemistry, Institute of Atmospheric PhysicsChinese Academy of Sciences, 100029, Beijing, China

* Corresponding author: Phone: +86-10-62771466; Email:

shxwang@tsinghua.edu.cn; fmyang@cigit.ac.cn

These authors contributed equally to this work: Jiandong Wang \& Bin Zhao 


\section{Abstract}

China is one of the regions with highest $\mathrm{PM}_{2.5}$ concentration in the world. In this study, we systematically review the spatio-temporal distribution of $\mathrm{PM}_{2.5}$ mass concentration and components in China and the effect of control measures on $\mathrm{PM}_{2.5}$ concentrations. Annual averaged $\mathrm{PM}_{2.5}$ concentrations in Central-Eastern China reached over $100 \mu \mathrm{g} / \mathrm{m}^{3}$, in some regions even over $150 \mu \mathrm{g} / \mathrm{m}^{3}$. In 2013, only $4.1 \%$ of the cities attained the annual average standard of $35 \mu \mathrm{g} / \mathrm{m}^{3}$. Aitken mode particles tend to dominate the total particle number concentration. Depending on the location and time of the year, new particle formation (NPF) has been observed to take place between about 10 and $60 \%$ of the days. In most locations, NPF was less frequent at high PM mass loadings. The secondary inorganic particles (i.e. Sulfate, Nitrate and Ammonium) ranked the highest fraction among the $\mathrm{PM}_{2.5}$ species, followed by organic matters (OM), crustal species and element carbon (EC), which accounted for 6-50\%, 15-51\%, $5-41 \%$ and $2-12 \%$ of $\mathrm{PM}_{2.5}$, respectively. In response to serious particulate matter pollution, China has taken aggressive steps to improve air quality in the last decade. As a result, the national emissions of primary $\mathrm{PM}_{2.5}$, sulfur dioxide $\left(\mathrm{SO}_{2}\right)$, and nitrogen oxides $\left(\mathrm{NO}_{\mathrm{X}}\right)$ have been decreasing since 2005,2006 , and 2012, respectively. The emission control policies implemented in the last decade could result in noticeable reduction in $\mathrm{PM}_{2.5}$ concentrations, contributing to the decreasing $\mathrm{PM}_{2.5}$ trends observed in Beijing, Shanghai, and Guangzhou. However, the control policies issued before 2010 are insufficient to improve $\mathrm{PM}_{2.5}$ air quality notably in future. An optimal mix of energy-saving and end-of-pipe control measures should be implemented, more ambitious control policies for NMVOC and $\mathrm{NH}_{3}$ should be enforced, and special control measures in winter should be applied, 40-70\% emissions should be cut off to attain $\mathrm{PM}_{2.5}$ standard.

Key words: $\mathrm{PM}_{2.5}$; number concentration; chemical speciation; control meaures; China 


\section{Contents}

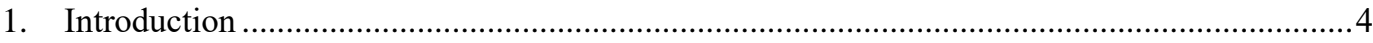

2. $\quad \mathrm{PM}_{2.5}$ mass concentration across China …………….........................................................

2.1. Spatial and temporal distribution of $\mathrm{PM}_{2.5}$ pollution...................................................

2.2. $\mathrm{PM}_{2.5}$ mass concentration in megacities......................................................................

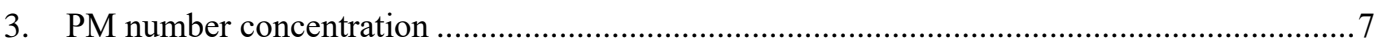

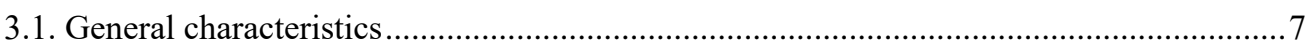

3.2. Connection with sources and pollution episodes ..........................................................

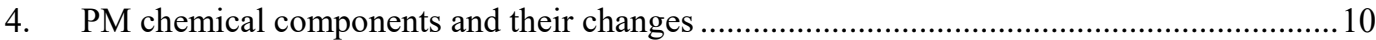

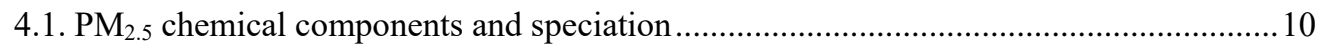

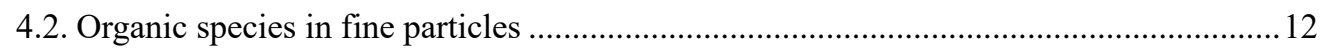

5. Effect of control measures on particulate matter pollution ................................................. 13

5.1. Recent control measures for particulate matter pollution.......................................13

5.2. Effect of recent control measures on air pollutant emissions and $\mathrm{PM}_{2.5}$ concentrations 16

5.3. Effect of future control measures on air pollutant emissions and $\mathrm{PM}_{2.5}$ concentrations 19

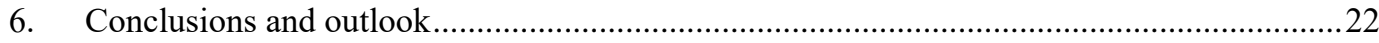

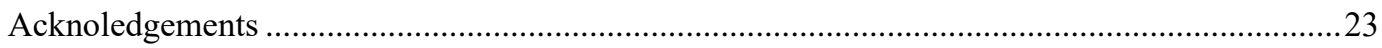

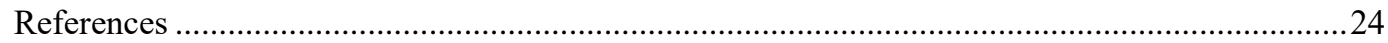




\section{Introduction}

China is one of the regions with highest concentration of fine particulate matter with aerodynamic diameter equal to or less than $2.5 \mu \mathrm{m}\left(\mathrm{PM}_{2.5}\right)$ in the world (van Donkelaar et al., 2015). With the rapid growth of economy and urbanization, the air pollution emissions continually increase since 2000 . The population-weighted average $\mathrm{PM}_{2.5}$ concentration reached $59 \mu \mathrm{g} / \mathrm{m}^{3}$ in 2010 . More than $80 \%$ people lived in the region where air quality did not reach the air quality standard $\left(35 \mu \mathrm{g} / \mathrm{m}^{3}\right)$ in 2010 (Apte et al., 2015). The premature mortality caused by $\mathrm{PM}_{2.5}$ is 1.27 million in China (Apte et al., 2015; Lim et al., 2012). Since June 2000, the Ministry of Environmental Protection of China (MEP) started to publish a daily air pollutant index (API), an integrated index calculated from daily concentrations of $\mathrm{SO}_{2}, \mathrm{NO}_{2}$, and $\mathrm{PM}_{10}$ (particulate matter with an aerodynamic diameter of $10 \mu \mathrm{m}$ or less). API data was used to estimate $\mathrm{PM}_{10}$ concentrations in 86 Chinese cities and to analyze the long-term variation of $\mathrm{PM}_{10}$ across China (Cheng et al., 2013; Qu et al., 2010; Yang, 2009). In 2012, China released a new ambient air quality standard, which was effective in January $1^{\text {st }}, 2016$, including $\mathrm{PM}_{2.5}$ as a pollutant for the first time (Jiang et al., 2015a). Following that, 74 Chinese cities including Beijing and Shanghai started to monitor hourly concentrations of $\mathrm{PM}_{2.5}, \mathrm{PM}_{10}, \mathrm{SO}_{2}, \mathrm{NO}_{2}, \mathrm{CO}$, and $\mathrm{O}_{3}$. Since January $1^{\text {st }}, 2013$, these data have been available to the public online in real time. By February 2014, the number of cities releasing hourly $\mathrm{PM}_{2.5}$ concentrations increased to 190 . This dataset offers a good opportunity for us to analyze the spatial distribution and interannual trend of $\mathrm{PM}_{2.5}$ concentration in China.

Faced with serious particulate matter pollution, China has taken substantial measures to improve energy efficiency and reduce emissions of air pollutants in the last decade. During the $11^{\text {th }}$ Five Year Plan period (2006-2010), the Chinese government set a target to reduce national $\mathrm{SO}_{2}$ emissions by $10 \%$. This target was overfilled, such that the emissions of total suspended particulate (TSP) and $\mathrm{SO}_{2}$ decreased from 2005 to 2010 by $39.0 \%$ and $14.3 \%$, respectively (Chinese Environmental Statistical Bulletin, http://zls.mep.gov.cn/hjtj/). During the $12^{\text {th }}$ Five Year Plan period (2011-2015), China planned additional $10 \%$, and $8 \%$ reductions for $\mathrm{NO}_{\mathrm{x}}$ emissions and $\mathrm{SO}_{2}$ emissions, respectively. Inspired by frequent, longlasting and large-scope heavy haze pollution in eastern China recently, especially in January 2013, Chinese government issued the "Action Plan on Prevention and Control of Air Pollution" in September 2013 (hereinafter referred to as Action Plan). It is valuable for both scientific research and decisionmaking to systematically evaluate the effect of these control measures on national and regional $\mathrm{PM}_{2.5}$ pollution. Moreover, given the elevated $\mathrm{PM}_{2.5}$ concentrations in China, current control legislations are still insufficient for the attainment of ambient air quality standard, which requires large and simultaneous reductions of both primary particles and multiple gaseous precursors (Wang and Hao, 2012). To guide future decision-making, we also need to evaluate how future control policies can alter emission trends and $\mathrm{PM}_{2.5}$ concentrations.

In this study, we first review the spatial distribution and temporal trend of $\mathrm{PM}_{2.5}$ mass concentration (Section 2), number concentration (Section 3), and its chemical components (Section 4). Then, we review the effect of recent and future control measures on particulate matter pollution in China (Section 5). Finally, we give suggestions for future control activities. 


\section{2. $\mathbf{P M}_{2.5}$ mass concentration across China}

\subsection{Spatial and temporal distribution of $\mathrm{PM}_{2.5}$ pollution}

Due to the limitation of $\mathrm{PM}_{2.5}$ observation network, only a few studies observed the spatial distribution of $\mathrm{PM}_{2.5}$ pollution. Wang et al. (2015c) reported concentrations of $\mathrm{PM}_{10}, \mathrm{PM}_{2.5}$ and $\mathrm{PM}_{1}$ monitored at 24 China Atmosphere Watch Network (CAWNET) stations from 2006 to 2014. In CAWNET, $\mathrm{PM}_{10}, \mathrm{PM}_{2.5}$, and $\mathrm{PM}_{1}$ concentrations were monitored by GRIMM EDM 180 environmental dust monitor instruments with 31 different size channels. The instrument is designed to measure the particle number size distribution and particulate mass, based on a light scattering measurement. GRIMM-developed protocols were used to convert the measured number size distribution to a mass concentration consistent with U.S. Environmental Protection Agency protocols for measuring PM using the aerodynamic diameter. Although several studies reported that results from GRIMM were comparable with those from tapered element oscillating microbalance (TEOM) (Grimm and Eatough, 2009; Hansen et al., 2010; Sciare et al., 2007; Zhao et al., 2011), but in China's thereafter $\mathrm{PM}_{2.5}$ network observation (especially in the CEPA's network), the main observation instruments used are beta attenuation monitor. Since 2008, U.S. diplomatic missions in Beijing, Shanghai, Guangzhou, Chengdu, and Shenyang have started to monitor $\mathrm{PM}_{2.5}$ concentrations using a beta attenuation monitor (BAM-1020, MetOne) and made that data available to the public (see www.stateair.net). The start date, geographic coordinates were shown in Table S1. Martini et al. (2015) analyzed the interannual trend, seasonal variation and diurnal variation of $\mathrm{PM}_{2.5}$ using this dataset. The 74 Chinese cities including Beijing and Shanghai started to monitor hourly concentrations of $\mathrm{PM}_{2.5}, \mathrm{PM}_{10}, \mathrm{SO}_{2}, \mathrm{NO}_{2}, \mathrm{CO}$, and $\mathrm{O}_{3}$ since January 1 $1^{\text {st }}, 2013 . \mathrm{PM}_{2.5}$ hourly concentrations were measured either by TEOM or by BAM. Qu et al. (2010) provided a review and analysis of China's air pollution from urban scale to regional scale based on the monthly reports from August 2013 to July 2014.

Figure 1 shows the average $\mathrm{PM}_{2.5}$ concentration of all sites in large and middle-size cities. As shown in Figure 1, from 2013 to 2015, the general spatial patterns are consistent, with higher $\mathrm{PM}_{2.5}$ in eastern China and lower pollution in western part. However, regions with annual $\mathrm{PM}_{2.5}$ over $80 \mu \mathrm{g} / \mathrm{m}^{3}$ (red dots in Figure 1a to 1c) is shrinking, from the whole North China Plain region (NCP) and Shanxi, Shannxi, Sichuan Province in 2013 to mainly the JJJ region in 2015. Figure 2 shows the comparison of China's air quality with that in Europe. The $\mathrm{PM}_{2.5}$ concentration from 1996 to 2007 of Europe is reproduced based on Putaud et al. (2010). As shown in Figure 2, the decreasing trend is more clearly seen when focusing on the JJJ, YRD and PRD region. The average $\mathrm{PM}_{2.5}$ concentration of JJJ, YRD, PRD decreased from 110,70 and $48 \mu \mathrm{g} / \mathrm{m}^{3}$ to 85,55 and $34 \mu \mathrm{g} / \mathrm{m}^{3}$, respectively. Only over half of the cities in PRD reached the air quality standard in 2015 , but still have a way to go to reach WHO guideline, and higher from Europe.

As shown in Figure 3, the ratio of annual average $\mathrm{PM}_{2.5}$ concentrations to $\mathrm{PM}_{10}$ showed a clear increasing trend from northern to southern China, which is also supported by Wang et al. (2015c). The isohyetal line was based on annual precipitation of 160 Chinese meteorological stations during 19712000 obtained from National Climate Center of China (reproduced from Ling et al., 2014). Clear gradient from north to south of $\mathrm{PM}_{2.5} / \mathrm{PM}_{10}$ are consistent with the isohyetal line. The lowest value (0.40-0.50) 
were seen in arid region of China, like Urumqi, Yinchuan and Hohhot, which are influenced by dust storm. The ratio in most cities in NCP, like Shijiazhuang, Taiyuan and Zhengzhou, are between 0.50-0.56, where annual precipitation is between $400 \mathrm{~mm}$ to $600 \mathrm{~mm}$. The ratio in Northeast China, Beijing and Tianjin are about $0.56-0.66$. It indicates that the values were influenced by fugitive dust due to the low precipitation amounts in northern China. The highest ratio was for the middle and lower reaches of YRD and PRD regions, which are characterized by the highest precipitation. The cities with best air quality, like Zhuhai, Haikou and Kunming, show a lower ratio of $\mathrm{PM}_{2.5}$ to $\mathrm{PM}_{10}$. This is mainly due to the low $\mathrm{PM}_{2.5}$ concentration.

In terms of seasonal variations, wintertime $\mathrm{PM}_{2.5}$ is always higher than that summertime $\mathrm{PM}_{2.5}$ in all Chinese cities,, as shown in Figure 4e. China is a major monsoon region. The seasonal variations are largely impacted by the variation of temperature and precipitation. The largest seasonal variations occurred in northern and southern China. The high winter/summer ratio in northeastern China is mainly due to the high winter $\mathrm{PM}_{2.5}$ concentration associated with heating from coal combustion. In Heilongjiang, Jilin and Liaoning Province, the low temperature in winter resulted in large demand for indoor heating. Taking Harbin as an example, The average temperature in winter is from -17 to $-6{ }^{\circ} \mathrm{C}$. Consequently, the corresponding high emissions resulted in high $\mathrm{PM}_{2.5}$ concentration of $136 \mu \mathrm{g} / \mathrm{m}^{3}$. In comparison, the summertime $\mathrm{PM}_{2.5}$ in Harbin is $33 \mu \mathrm{g} / \mathrm{m}^{3}$, which is comparable with the JJ region (Figure $4 \mathrm{~b}$ ). The high winter-summer ratios in the most south marine China (mainly PRD region), in contrast, is mainly due to its low summer $\mathrm{PM}_{2.5}$ level. As precipitation in this region is much more abundant in summer than winter in this region (Taking Guangzhou as an example, the average precipitation from 1971 to 2000 was 736 $\mathrm{mm}$ in summer while $108 \mathrm{~mm}$ in winter), the wet depositions can efficiently remove the $\mathrm{PM}_{2.5}$ in summer (Andronache, 2003; Sparmacher et al., 1993). Average summer $\mathrm{PM}_{2.5}$ concentration in Guangzhou is only $27 \mu \mathrm{g} / \mathrm{m}^{3}$, which is lower than the northern provinces like Fujian, Hunan and Jiangxi. In comparison, winter $\mathrm{PM}_{2.5}$ in Guangzhou is usually $62 \mu \mathrm{g} / \mathrm{m}^{3}$, which is comparable with other southern provinces (Figure 4d).

In terms of spatial distribution, the seasonal variations showed both commonalities and differences. For all the major areas of JJJ, YRD and PRD, the winter-peak and summer-trough pattern is always observed. However, the pollution levels of spring and autumn are not the same. For JJJ and PRD area, $\mathrm{PM}_{2.5}$ in spring is usually lower than autumn, while the trend in the YRD is the opposite.

The outbreak of the haze episodes also have strong seasonal characteristics. Zheng et al. (2016) and Cheng et al. $(2013,2014)$ analyzed the episode pattern and caused of Beijing and YRD with year-long observation data, respectively. Severe haze episodes frequently occurred in winter, June, and October for both regions. In spring, the dominant type is mixed haze-dust. The ratio of $\mathrm{PM}_{2.5}$ in $\mathrm{PM}_{10}$ is minimum among four seasons. The contribution of crustal elements increases. The severe pollution in summer is related to the intensive biomass-burning activities. The contribution of OM and EC increases during the episodes. In fall and winter, the episodes are linked to unfavorable synoptic conditions, like stable Planetary Boundary Layer (PBL) and low wind speed. Regional transport also plays an important role during the heavy pollution episodes (Zheng et al. (2016). The increase of SNA is mainly attributed to the heavy pollution episodes. 


\section{2. $\mathrm{PM}_{2.5}$ mass concentration in megacities}

Figure 5 presents the $\mathrm{PM}_{2.5}$ observation studies in three megacities, i.e., Beijing (a), Shanghai (b), and Guangzhou (c). The detail sampling and chemical analysis method are listed in the Tables S2, S3, and S4, respectively. As shown in Figure 5 (Cao et al., 2012; Chen et al., 2014; Dan et al., 2004; Duan et al., 2006; Han et al., 2005; He et al., 2001; Jung et al., 2009; Lin et al., 2009; Schleicher et al., 2010; Shi et al., 2003; Song et al., 2012; Sun et al., 2004; Wang et al., 2009; Wang et al., 2007; Wang et al., 2005; Yang et al., 2011a; Yu et al., 2013; Yu et al., 2014; Zhang et al., 2013; Zhao et al., 2013e; Zhao et al., 2009), the $\mathrm{PM}_{2.5}$ mass concentrations decreased from $147 \mu \mathrm{g} / \mathrm{m}^{3}$ in 2002 to $81 \mu \mathrm{g} / \mathrm{m}^{3}$ in 2015. All observations far exceed the national standard level 2, i.e. annual average of $35 \mu \mathrm{g} / \mathrm{m}^{3}$, according to the National Ambient Air Quality Standards (GB3095-2012). Different from ground-based studies, AOD in Beijing shows a slowly increase trend in Beijing (Peng et al., 2016) from 1999 to 2011. It might be caused by several reasons. First, AOD is the column-sum of aerosol extinction. The upper extinction represents more like regional characteristics. During that period, the emission in Hebei Province increases a lot, which impacts the AOD value in Beijing. Second, the mass extinction coefficient might increase due to the change of component and size distribution of $\mathrm{PM}_{2.5}$ during 1999 to 2011. Besides, the variation of PBL height might also cause this effect.

Similarly to that in Beijing, the $\mathrm{PM}_{2.5}$ concentration in Shanghai, as shown in Figure 5b, also showed a generally decreasing trend, from $95 \mathrm{ug} / \mathrm{m}^{3}$ in 2004 to $53 \mathrm{ug} / \mathrm{m}^{3}$ in 2015 (Cao et al., 2013; Du et al., 2011; Feng et al., 2009; Huang et al., 2012a; Kan et al., 2007; Wang et al., 2016; Wang et al., 2015a; Wang et al., 2006b; Xu et al., 2002; Zhang et al., 2015b; Zhao et al., 2015a). Since 2010, the level showed a somewhat stable value around $55 \mathrm{ug} / \mathrm{m}^{3}$, which is about $30 \%$ lower than the average level in Beijing. Another interesting feature is that suburban $\mathrm{PM}_{2.5}$ level (Jiading District) in Shanghai is generally higher than the urban level. Moreover, this feature is not seasonal-specific, as it was observed in annual average (e.g., in 2006), in winter 2005 as well as in summer 2006 (Feng et al., 2009). This phenomenon can be explained by the impact of regional transport from northern part, or a possible influence from substantial secondary aerosols in downwind of megacities.

Not like that in Beijing and Shanghai, $\mathrm{PM}_{2.5}$ in Guangzhou, shown as Figure 5c, showed more significant decreasing trend until 2015. The concentration level has fallen from $91 \mathrm{ug} / \mathrm{m}^{3}$ in 2002 to 39 $\mathrm{ug} / \mathrm{m}^{3}$ in 2015 , with a decreasing rate of $57 \%$. In 2015 , the annual average $\mathrm{PM}_{2.5}$ concentration in Guangzhou reached about $35 \mathrm{ug} / \mathrm{m}^{3}$. The low $\mathrm{PM}_{2.5}$ concentration in Guangzhou is caused by several reasons. First, as shown in Figure 5 (c), the precipitation in Guangzhou is much higher than that in Beijing. The plentiful rainfall benefits the removal of air pollution. And the emission intensity in PRD is smaller than JJJ and YRD (Zhao et al., 2013a). Judging from the observation in 2002, Guangzhou also showed the trend of suburban-high and urban-low pattern as that in Shanghai, which might be attributed to the shift in economic and industrial structures over the decade.

\section{PM number concentration}

\subsection{General characteristics}


Table 1 summarizes the observed total and size-segregated particle number concentrations for those published data sets that cover at least one year of measurements. We can see that the site-average total particle number concentration varies from about 2,000 $\mathrm{cm}^{-3}$ at a remote high-altitude site (Waliguan, 3.8 $\mathrm{km}$ above sea level) to values in excess of $20,000 \mathrm{~cm}^{-3}$ in urban areas. In addition to these data, Peng et al. (2014) reported similar data from 13 sites based on field measurement campaigns that lasted from a few weeks to a couple of months between 2007 and 2011. They found that the average total particle number concentration varied between 13,700 and 28,400 $\mathrm{cm}^{-3}$ in urban sites, between 10,200 and 16600 $\mathrm{cm}^{-3}$ in regional sites, and between 5,700 and $7,200 \mathrm{~cm}^{-3}$ in coastal or background sites. The total particle number concentrations reported in the urban areas of China are comparable to those measured in European urban environments (Hofman et al., 2016; Putaud et al., 2010). In China, total particle number concentrations do not decrease much when moving from urban to rural or even remote environments. This is contrary to Europe where the average total particle number concentrations are typically between about 1,000 and $5,000 \mathrm{~cm}^{-3}$ in rural environments and mostly below $1,000 \mathrm{~cm}^{-3}$ in rural environments (Asmi et al., 2011; Putaud et al., 2010).

Sub-micron particles are usually divided into three modes: the nucleation mode (particles smaller than about 20-30 nm in diameter), Aitken mode (particles from 20-30 nm up to about $100 \mathrm{~nm}$ in diameter) and accumulation mode (particles larger than about $100 \mathrm{~nm}$ in diameter). In China, Aitken mode particles tend to dominate the total particle number concentration (Table 1, Peng et al., 2014), which is similar to observations made in Europe (Asmi et al., 2011). Exceptions for this feature are the periods of active new particle formation when high concentrations of nucleation mode particles are present, as well as highly-polluted conditions when a big share of the total particle number concentration may be located in the accumulation mode size range (section 4.2).

Total particle number concentrations seem to have a relatively weak annual cycle in China, with the reported seasonally-averaged particle number concentrations being typically within a factor two at individual sites (Kivekäs et al., 2009; Qi et al., 2015; Shen et al., 2016b; Shen et al., 2011; Wu et al., 2008; Zhao et al., 2015b). In most locations, the total particle number concentration tend to be the highest in spring. The seasonal cycles of particle concentrations in different size modes do not show any consistent pattern between the different sites, even though the available data are too few for drawing a firm conclusion on whether such a pattern might exist.

For all sites in Table 1, the diurnal cycle of the particle number concentration was found to be the strongest for nucleation mode particles and weakest for accumulation mode particles. The strong diurnal cycle of nucleation mode particles is quite expected, as these particles have much shorter atmospheric lifetimes than either Aitken or accumulation mode particles (e.g. Williams et al., 2002), in addition to which their main sources are active mainly during the daytime. The less pronounced diurnal variability of accumulation mode particles compared with Aitken mode particles can be explained by their longer atmospheric lifetime, perhaps combined with less severe influence by local primary particle sources (e.g. Paasonen et al., 2016).

To our knowledge, no continuous long-term measured data on particle number concentrations (to be able to perform trend analysis) have been published for China. We are therefore not able to estimate trends in PM number concentrations in China similar to PM mass concentrations (see sections 2.1 and 2. 
2). However, measurements made during several summers before, and during, the 2008 summer Olympic Games in Beijing showed that the pollutant emission reductions implemented during the Olympics decreased considerably the average particle number concentrations in different size modes (Wang et al., 2013b). This suggests that past changes in air pollutant emissions in Chinese megacities have influenced not only PM mass concentrations, but also particle number concentrations.

\subsection{Connection with sources and pollution episodes}

The particle number concentration and size distribution at any location is a net result of primary particle emissions into the atmosphere, formation of new aerosol particles in the atmosphere, and transformation of the aerosol population by various growth and removal processes during their atmospheric transport to the location of interest (e.g. Raes et al., 2000). Based on a very recent emissions inventory (Paasonen et al., 2016), the most important primary particle sources in China was estimated to be power production followed by residential and industrial combustion. Road traffic, while estimated to be the most important primary particle source in Europe, Northern and Southern America, Australia and in large parts of Asia, ranks only the fourth primary particle source in China. In terms of the particle number concentration, more than $70 \%$ of the emitted primary particles were estimated to be in the Aitken mode in China (Paasonen et al., 2016).

Since the first reported observations by Wehner et al. (2004) in Beijing for more than a decade ago, atmospheric new particle formation (NPF) has been recognized to be a potentially very important source of aerosol particles in China (see Kulmala et al., 2016b; Peng et al., 2014; Shen et al., 2016a; and references therein). Depending on the location and time of the year, NPF has been observed to take place between about 10 and $60 \%$ of the days. In most locations, NPF was found to less frequent at high PM mass loadings. However, contrary to theoretical expectations (Kulmala et al., 2016b), NPF has in some cased observed to take place even under extremely polluted conditions in China (Nie et al., 2014; Wang et al., 2013c; Xiao et al., 2015). Reported growth rates of particles formed by atmospheric NPF range typically from a few $\mathrm{nm} /$ hour up to about $20 \mathrm{~nm} /$ hour in China, which means that these particles tend to grow into the Aitken mode within a few hours. Further growth of these particles to the sizes at which they may act as cloud condensation nuclei (CCN), i.e. larger than about 50-100 nm in diameter (Kerminen et al., 2012), will take from a few hours to a couple of days.

Distinguishing between primary particles and particles formed by atmospheric NPF is difficult, especially in urban areas (e.g. Ma and Birmili, 2015). This difficulty is also apparent when looking at the few source apportionment studies made for PM number concentrations in China (e.g. Liu et al., 2016b; Tan et al., 2014). Kulmala et al. (2016a) refined the black carbon tracer method introduced by Rodríguez and Cuevas (2007) for separating secondary particles from primary ones based on atmospheric observations. They applied this method for more than a year of continuous measurements in a sub-urban site in Nanjing, China, and estimated that on average about half of the measured accumulation mode particles and more than $80 \%$ of the sub- $100 \mathrm{~nm}$ particles were formed by atmospheric NPF in this environment. A number of studies have investigated CCN production associated with NFP in China (e.g. Peng et al., 2014; Shen et al., 2016a; Wang et al., 2013a; Wiedensohler et al., 2009). These studies report large enhancements in $\mathrm{CCN}$ concentrations after NPF and subsequent particle growth, and suggest that the fraction of CCN originating from NPF may exceed 50\% during the seasons with active NPF. 
Furthermore, there are indications that the contribution of NPF to CCN might be higher for urban sites compared with rural or more remote sites (Peng et al., 2014). Put together, it is evident that both primary and secondary particles need to be considered when studying the environmental, health and climatic effects of atmospheric aerosol particles in China.

Formation and evolution of air pollution episodes provide unique cases to investigate how PM number concentrations and size distributions are connected with PM mass concentrations. Based on measurements in Beijing, Guo et al. (2014) showed that clean periods with low PM mass concentrations were often accompanied by strong atmospheric NPF, resulting in high total particle number concentrations with number mean diameters well below $50 \mathrm{~nm}$. During the transition from clean to polluted periods, both PM mass concentration and particle number mean diameter increased considerably, whereas NPF became less frequent and weaker so that the total particle number concentration first decreased and then fluctuated at around a relatively constant level. Liu et al. (2016a) found that the transition from clean to polluted conditions can take place rapidly, within a few hours, or then over a period of several days. They also found that the ratio between accumulation mode and Aitken mode particles was clearly higher during more polluted conditions. This suggests that both newly-formed and primary particles are capable of growing into the accumulation mode during the transition from clean to polluted conditions, highlighting the very dynamic nature of the sub-micron particle population in the urban air of China.

\section{PM chemical components and their changes}

\section{1. $\mathrm{PM}_{2.5}$ chemical components and speciation}

$\mathrm{PM}_{10}$ components and their changes are briefly presented based on long-term observations during 2006-2013 in the Atmosphere Watch Network (CAWNET), which covers various regions of China and includes urban, rural and remote sites (Zhang et al., 2015d; Zhang et al., 2012). This section mainly focuses on $\mathrm{PM}_{2.5}$ components over China. Based on the recent studies covering at least one-year observation with bulk chemical composition, chemical species in $\mathrm{PM}_{2.5}$ measured during 2009-2015 in 23 provincial capitals and all the 4 municipalities directly under central government were assembled to perform their speciation reconstruction and compare their spatial and temporal variations. A brief introduction of the locations, sampling and analyses, and PM mass concentrations for all these studies are listed in Table S5.

Chan and Yao (2008) have summarized chemical compositions in $\mathrm{PM}_{2.5}$ in a critical review about air pollution in China, with a focus on Beijing, Shanghai, Pearl Delta Region (including Guangzhou, Shenzhen and Hong Kong) and immediate vicinities. Later on, Yang et al. (2011b) tried to present a relatively big picture of reconstructed $\mathrm{PM}_{2.5}$ speciation composition based on the studies conducted in 16 locations across China during 1999-2007. It focused on characterization and comparison of temporal and spatial variations in the $\mathrm{PM}_{2.5}$ speciation composition at paired rural/urban sites in several representative megacities.

As illustrated in Figure 6, the magnitude and spatial pattern of $\mathrm{PM}_{2.5}$ mass and chemical speciation varied noticeably over geographic regions in China. The annual mean concentrations of $\mathrm{PM}_{2.5}$ mass and chemical components in the 27 major cities are classified into seven geographic regions over China 
(Figure 6). In general, those cities in North, Central, East, Southern regions represent relatively developed regions, while Southwest, Northeast and Northwest China represent less developed regions.

The magnitude and spatial pattern of $\mathrm{PM}_{2.5}$ mass and chemical speciation varied noticeably over geographic regions. North region suffered the most severe $\mathrm{PM}_{2.5}$ pollution $\left(159 \mu \mathrm{g} \mathrm{m}^{-3}\right)$, followed by Northwest $\left(136 \mu \mathrm{g} \mathrm{m}^{-3}\right)$ and Central China $\left(122 \mu \mathrm{g} \mathrm{m}^{-3}\right)$, while the South region was barely satisfactory $\left(66.6 \mu \mathrm{g} \mathrm{m}^{-3}\right)$. Annual mean concentrations of $\mathrm{PM}_{2.5}$ ranged from 25.0 to $273 \mu \mathrm{g} \mathrm{m}^{-3}$, with the highest concentration in Taiyuan in North China and the lowest in Lhasa in Southwest China. Besides Lhasa, only Haikou in South region met the secondary grade mass concentration limit of the National Ambient Air Quality Standards (NAAQS) in China $\left(35 \mu \mathrm{g} \mathrm{m}^{-3}\right)$. By contrast, there are 11 cities with average $\mathrm{PM}_{2.5}$ mass in excess of $100 \mu \mathrm{g} \mathrm{m}^{-3}$, among which 5 of 6 cities lie in North, 3 of 4 cities in Northwest China.

Compared to the results by Yang et al. (2011b), $\mathrm{PM}_{2.5}$ mass in Chongqing decreased largely from $129 \mu \mathrm{g} \mathrm{m}^{-3}$ in 2005 to $73.8 \mu \mathrm{g} \mathrm{m}^{-3}$ in 2012, while the changes were not so evident in Beijing, Shanghai, and Guangzhou during the same period. Compared to annual average concentrations in 2015 released by each city's environmental statement, it is common to see the significant reduction. For examples, the values decreased from 123 to $80.6 \mu \mathrm{g} \mathrm{m}^{-3}$ during 2009-2015 in Beijing, from 76.8 to $39.0 \mu \mathrm{g} \mathrm{m}^{-3}$ during 2009-2015 in Guangzhou, and from $73.8 \mu \mathrm{g} \mathrm{m}^{-3}$ to $57.0 \mu \mathrm{g} \mathrm{m}^{-3}$ during 2012-2015 in Chongqing.

SNA and $\mathrm{OM}$ were the dominant components of $\mathrm{PM}_{2.5}$ across China. Their mass percentages (sulfate, nitrate, and ammonium separately except in Haikou) and those of other constitutes are diagrammed in Figure 7. OM plus SNA accounted for 35-78\% of $\mathrm{PM}_{2.5}$ mass in all the cities except those devoid of relevant data (i.e., Hefei, Haikou, Lanzhou), which was lower than that (62-90\%) in the previous study (Yang et al., 2011b). SNA constituted 6.0-50\% of $\mathrm{PM}_{2.5}$ with an average value of $34 \%$ across China. SNA mass exhibited a clear decreasing gradient from the North and East to the South and Southwest China: the annual mean SNA concentrations were 50.8, 40.5, 23.0 and $22.3 \mu \mathrm{g} \mathrm{m}^{-3}$ in North, East, South and Southwest, respectively. In fact, these regional distribution features of secondary inorganic aerosol were largely coincident with the intensity of industrial development, urbanization and nitrogen fertilizer applications. The maximum SNA level $\left(84.5 \mu \mathrm{g} \mathrm{m}^{-3}\right)$ and fraction (50\%) in $\mathrm{PM}_{2.5}$ mass both appeared in Jinan, and the mass concentration was higher than the value during the period of 2006-2007 (68.9 $\mu \mathrm{g} \mathrm{m}^{-}$ ${ }^{3}$ ) (Yang et al., 2011a). In Beijing, the fraction was up to $46 \%$ and showed a clear growth as well (Yang et al., 2011a). In contrast, extremely low SNA fractions were observed in Kunming (6.0\%) and Lhasa (7.8\%). It should still hold that the emission intensities of $\mathrm{SO}_{2}$ and $\mathrm{NO}_{2}$ in the developed regions are three to four times their corresponding national averages (Yang et al., 2011b), although the mega cities over China have kept controlling coal consumption and enhancing flue gas desulfurization in recent years.

Much higher $\mathrm{SO}_{4}{ }^{2-}$ levels $\left(>30 \mu \mathrm{g} \mathrm{m}^{-3}\right)$ were observed in the industrial cities with high coal consumption intensity in North China, such as Shijiazhuang, Taiyuan and Jinan, especially for the latter. In Jinan, $\mathrm{SO}_{4}{ }^{2-}$ accounted for $30 \%$ of $\mathrm{PM}_{2.5}$ mass, the highest fraction among all the cities, matching the capital city of Shandong province as the maximum anthropogenic $\mathrm{SO}_{2}$ emissions on a provincial basis. By contrast, the lowest values were seen in Southwest and South China, where there existed frequent acidic precipitations since 1970's or later. On average, the annual mean $\mathrm{SO}_{4}{ }^{2-}$ concentrations in North China were higher than that in South China by near $10 \mu \mathrm{g} \mathrm{m}^{-3}$. This was partially due to additional use of coal for space heating from late fall through early spring in North China due to cold weather. 
$\mathrm{NO}_{3}{ }^{-}$exhibited a similar spatial distribution with the highest concentrations in North China, followed by Central and East China. The highest concentration was seen in Shijiazhuang, while the lowest concentrations were observed in Kunming and Lhasa. It was evident that both concentrations of $\mathrm{NO}_{3}{ }^{-}$and $\mathrm{NH}_{4}{ }^{+}$and their fractions in $\mathrm{PM}_{2.5}$ mass increased constantly in recent years in the cities with data for comparison. Take Beijing for example, $\mathrm{NO}_{3}{ }^{-}$fraction was much higher in $2012(16 \%)$ (Zhang et al., 2015a) compared to those during the period of 2000-2009 (6.0-9.0\%) while $\mathrm{SO}_{4}{ }^{2-}$ fraction was relatively constant (Yang et al., 2011b; Zhang et al., 2013). As a result, the mass ratio of $\left[\mathrm{NO}_{3}{ }^{-}\right] /\left[\mathrm{SO}_{4}{ }^{2-}\right]$ exhibited noticeably growth, likely indicative of enhanced contribution to fine particle pollution in Beijing from mobile sources over stationary sources. It is worthy of note that this phenomenon has been becoming more and more prominent across China, since the emissions of their gaseous precursors $\left(\mathrm{NO}_{\mathrm{x}}\right.$ and $\mathrm{SO}_{2}$ ) is experiencing contrary shifts.

The annual mean concentrations of $\mathrm{NH}_{4}{ }^{+}$in North and Central China were about twice those in South and Southwest China, while the values in East and Northwest China were comparable. On the basis of single city, Zhengzhou and Taiyuan had much higher $\mathrm{NH}_{4}{ }^{+}$concentrations than other cities. As particulate $\mathrm{NH}_{4}{ }^{+}$is mainly formed from gaseous $\mathrm{NH}_{3}$ and acidic species through complicated gas-phase and aqueous-phase reactions, and $\mathrm{NH}_{3}$ emission is not so clear as $\mathrm{NO}_{\mathrm{x}}$ and $\mathrm{SO}_{2}$, the reason for its regional difference is unclear.

OM accounted for $15-51 \%$ of $\mathrm{PM}_{2.5}$ mass, thus was a relatively constant and significant contributor to fine particles across China. It is noted that the annual mean concentrations of OM were remarkably higher in North China than in other regions. Unlike the spatial distribution of SNA, the proportion of OM in all the five cities in Southwest China remained larger than in other regions. It is noteworthy that in 408 Kunming and Lhasa, two plateau cities, OM concentrations were near six-fold larger than SNA concentrations. OM fraction in Lhasa was up to $51 \%$. Along with this highest fraction was the high mass ratio of OC to EC (10.2), likely pointing to predominant formation of secondary organic aerosol through photochemical reaction. This supposition was reasonable, owing to strong solar radiation ( $>7500 \mathrm{MJ}$ $\mathrm{m}^{-2}$ ) over Tibetan Plateau (Ling et al., 2014). This high OC content and OC/EC ratio, together with low sulfate content implied that frequent biomass burning in this region likely played an important role as well.

Crustal material is also a major component of $\mathrm{PM}_{2.5}$ in China. Its contribution rose dramatically in certain areas and during certain periods susceptible to be influenced by dust events or relevant anthropogenic activities (Yang et al., 2011b). Thus there existed a great spatial difference (from 5\% to $41 \%$ ) and seasonal variations for its loading and fraction in $\mathrm{PM}_{2.5}$ mass. In Northwest China with relatively less vegetation and more arid and semi-arid deserts, crustal material accounted for $41 \%, 23 \%$ and $25 \%$ of $\mathrm{PM}_{2.5}$ mass in Yinchuan, Xi' an and Lanzhou, respectively, whereas in East region the fraction dropped to as low as $5 \%$.

Annual mean concentrations of EC presented a similar spatial distribution as that of $\mathrm{NO}_{3}{ }^{-}$, which were highest in North China, and ranged from 1.0 (Lhasa) to $9.9 \mu \mathrm{g} \mathrm{m}^{-3}$ (Hangzhou) across China. The fraction of $\mathrm{EC}$ in $\mathrm{PM}_{2.5}$ ranged from 2\% to $12 \%$ with an average value of 6\%. Compared to the earlier results summarized by Yang et al. (2011b), the annual concentrations of EC were decreased more or less in Beijing, Chongqing, and Shanghai, varying from 8.2 to $6.3 \mu \mathrm{g} \mathrm{m}^{-3}, 6.4$ to $4.0 \mu \mathrm{g} \mathrm{m}^{-3}, 6.5$ to $1.9 \mu \mathrm{g} \mathrm{m}^{-}$ 
${ }^{3}$, respectively.

\subsection{Organic species in fine particles}

Organic matter is an important part of the atmospheric aerosols, usually accounting for $20-50 \%$ of $\mathrm{PM}_{2.5}$ (Gu et al., 2010). However, due to the huge number of organic compounds with various properties presented in aerosols and analytical difficulties, identified organic compounds typically account for $10 \%$ or less of OM mass. The percentage could reach above $60 \%$ by adopting more complex analytical procedure (Chang et al., 2009). The identified organic compounds mainly include n-alkanes, polycyclic aromatic hydrocarbons and some polar organic compounds such as organic acids, alcohol, aldehyde, ketone, and monosaccharide. The polar organic compounds contribute about $20-60 \%$ of solvent extractable organic compounds (SEOC). These SEOC are of great interesting as they contain useful molecular markers which have been successfully used for source identification and source apportionment (Chang et al., 2009; Feng et al., 2015b; Feng et al., 2012b).

Table 2 summarizes the concentrations of some important and ubiquitous SEOC in different areas in China. The total concentration of identified species contributes $3-11 \%$ of OC mass. Fatty acid usually had the highest proportion. The concentrations of alkanes, sugars and phthalates also exhibited high levels. No significant temporary changes were observed for alkanes, fatty acid, and $\mathrm{PAH}$ in $\mathrm{PM}_{2.5}$ in Shanghai. Contrarily, the average concentration of alkanes in $\mathrm{PM}_{2.5}$ in Beijing during 2006-2007 increased by a factor of 2.1 than that in 2002 whereas that of fatty acids decreased by $36 \%$ during this period.

Besides the perspective of SEOC, many studies have targeted water soluble organic carbon (WSOC) as well because of its important role on hygroscopicity and cloud condensation nuclei activities (Raes et al., 2010). However, identified species including organic acids and some sugars only accounted for about $20 \%$ of WSOC. Humic-like substances (HULIS) have a considerable concentration and are of importance in WSOC (Zhang et al., 2010). Their concentrations varied from 1 to $13 \mu \mathrm{g} \mathrm{m}^{-3}$ with their carbon fraction contributing 9-72\% of WSOC (Zhang et al., 2010). HULIS contains a high density of quinoid units and carboxylate groups but the specific components of HULIS are still unresolved (Zhu et al., 2012).

\section{Effect of control measures on particulate matter pollution}

\subsection{Recent control measures for particulate matter pollution}

The changes of $\mathrm{PM}_{2.5}$ concentrations are largely driven by air pollution control policies and measures. Our previous papers (Wang and Hao, 2012; Wang et al., 2014b) have reviewed China's air pollution control policies and measures as by 2012. In this study, we briefly summarize the control policies before 2010 and focus on the control policies and measures issued after 2010 .

China has a long history of controlling particulate matter pollution. In 2006, China set a target to reduce energy use per unit of Gross Domestic Product (GDP) by $20 \%$ and national $\mathrm{SO}_{2}$ emissions by $10 \%$ during the " $11^{\text {th }}$ five year plan (2006-2010)". It turned out that national energy use per unit of GDP, $\mathrm{SO}_{2}$ emissions, and TSP emissions decreased by 19.1\%, 14.3\%, and 39.0\% from 2005 to 2010 (Chinese Environmental Statistical Bulletin, http://zls.mep.gov.cn/hjtj/; The State Council of the People's Republic of China, 2011). During the $12^{\text {th }}$ Five-Year Plan period (2011-2015), China planned additional $16 \%, 10 \%$, and $8 \%$ reductions for energy use per unit GDP, $\mathrm{NO}_{\mathrm{X}}$ emissions, and $\mathrm{SO}_{2}$ emissions, respectively (The 
State Council of the People's Republic of China, 2011). Due to frequent and extensive haze episodes since 2011, the Chinese government has taken the most stringent air pollution control measures in history, and released the "Action Plan on Prevention and Control of Air Pollution" in September 2013 (referred to as "Action Plan") (The State Council of the People's Republic of China, 2013). This plan, for the first time, set clear targets for the improvement of environmental quality, i.e., the $\mathrm{PM}_{2.5}$ concentrations should be reduced by $25 \%, 20 \%$, and $15 \%$ in the JJJ region, the YRD region, and the PRD region, respectively, measured in 2017 against the 2012 levels. In all other prefecture-level cities, the $\mathrm{PM}_{10}$ concentrations are required to be reduced by $10 \%$ during the same period. The "Action Plan" also set up 10 types of measures, including 35 specific measures to assure the achievement of the environmental goals. The release of "Action Plan" marks the transformation from emission-oriented control policies to air qualityoriented control policies in China. The specific control policies and measures released after 2010 and the implementation status as of 2015 are described as follows.

According to the "Action Plan", the share of coal in total energy consumption would be decreased to $65 \%$ or less by 2017 , and total coal consumption would also decrease during 2012-2017 in the three key metropolitan regions. In 2015, the total coal consumption was 2.75 Gtce, $25 \%$ higher than that of 2010 but 3.7\% lower than that of 2014 (National Bureau of Statistics, 2011, 2016). The share of coal in total energy consumption decreased from $68.0 \%$ in 2010 to $64.0 \%$ in 2015 , attaining the $65 \%$ target set in the "Action Plan" two years ahead. Accordingly, the share of clean and renewable energy (including natural gas, nuclear power, hydro power, and wind power) increased from $13.0 \%$ in 2010 to $17.9 \%$ in 2015 , due to the promotion of clean energy power and the replacement of coal with clean energy (National Bureau of Statistics, 2011, 2016). Besides, the "Action Plan" demands that more than $70 \%$ of raw coal should be prepared and separated before being used by 2017. By the end of 2015, the national capacity for preparation and separation of raw coal reached $2.6 \mathrm{Gt}$, resulting in a preparation and separation fraction of $65.9 \%, 15 \%$ higher than that of 2010 (China National Coal Association, 2016).

Another important measure is eliminating outdated production capacity which has low energy efficiency and high emission rates. The "Action Plan" requires that coal-fired boilers under 10t/h should be phased out by 2017 and those under 20t/h should not be constructed in urban areas (The State Council of the People's Republic of China, 2013). By 2015, the JJJ region has successfully phased out small coalfired boilers with capacity less than $10 \mathrm{t} / \mathrm{h}$ in urban areas, and the YRD region and PRD region have also phased out most of the smaller boilers required to be eliminated. In addition, China has eliminated 44 million tons of iron capacity, 86 million tons of steel capacity, 263 million tons of cement capacity, and 86 million weight boxes of flat glass capacity during 2013-2015 (Chinese Academy of Engineering, 2016).

"Yellow Label" vehicles, that is, the pre-China I light duty vehicles and pre-China III heavy duty vehicles, accounted for about $10 \%$ of the vehicle population but as much as about $50 \%$ of emissions of major air pollutants from on-road vehicles in the end of 2013 (Ministry of Environmental Protection of China, 2014c). During 2013-2015, China has phased out about 15.3 million Yellow Label vehicles (Chinese Academy of Engineering, 2016). The remaining Yellow Label vehicles by the end of 2015 are less than 5.7 million (Clean Air Asia, 2015; Ministry of Environmental Protection of China, 2015a), which are expected to be eliminated by the end of 2017 according to the "Action Plan". Besides, in 2012, 
the central government released an ambitious plan to develop China's domestic electric vehicle industry and markets, setting a target of accumulated production and sales of EVs up to 5 million by 2020. In 2015, China's annual EV sales increased to 331 thousand, accounting for $1.3 \%$ of its total vehicle sales and a significant jump compared with the $0.3 \%$ sales share in 2014 (Wu et al., 2016).

China also made tremendous progress in the installation of flue gas desulfurization and flue gas denitrification facilities. The total capacity of coal-fired power plants equipped with flue gas desulfurization facilities increased from $530 \mathrm{GW}$ (83\%) in 2010 to $890 \mathrm{GW}$ (over 99\%) in 2015, and the capacity of those equipped with flue gas denitrification facilities increased from $80 \mathrm{GW}(12 \%)$ to 830 GW (92\%). During 2011-2015, the capacities of sintering machines equipped with flue gas desulfurization and precalcined cement kilns equipped with flue gas denitrification increased from 29 thousand $\mathrm{m}^{2}(19 \%)$ and near zero to 138 thousand $\mathrm{m}^{2}(88 \%)$ and $1600 \mathrm{Mt}(92 \%)$, respectively (Ministry of Environmental Protection of China, 2016). Except for the emission sources above, all catalytic cracking units of petroleum refineries, non-ferrous metal smelting plants, and coal-fired boilers above 20t/h shall install FGD by 2017. The dust-removal facilities of coal-fired boilers and industrial kilns are also required to be upgraded by 2017 (The State Council of the People's Republic of China, 2013). Stringent emission standards for a variety of industries have been rapidly issued since 2010 (Wang et al., 2014b). The "Action Plan" demands that special emission limits be established for 25 key industries; by 2015, national emission standards for all these key industries have been developed and released (Guo, 2015). In 2015, Chinese government set a new target that all eligible coal-fired power plants should attain an "ultralow" emission standard by 2020, with in-stack concentration limits of $10 \mathrm{mg} / \mathrm{m}^{3}, 35 \mathrm{mg} / \mathrm{m}^{3}$, and $50 \mathrm{mg} / \mathrm{m}^{3}$, for TSP, $\mathrm{SO}_{2}$, and $\mathrm{NO}_{\mathrm{x}}$, respectively (Ministry of Environmental Protection of China, 2015b).

China has periodically tightened emission standards for new vehicles and engines based on the European Union standards since 2000 (Wang et al., 2014b). The China IV standard (consistent with Euro IV) for light-duty vehicles was put into effect in 2011. The China IV standard (consistent with Euro IV) for heavy-duty diesel vehicles was originally planned for implementation in 2010, but it was postponed several times until the final enforcement at the beginning of 2015 (Ministry of Industry and Information Technology of China, 2014). The China V emission standard was adopted by Beijing, Tianjin, Shanghai, and some cities in the PRD region before the end of 2015, and by eleven provincial-level regions in Eastern China in April 2016. The scheduled nationwide implementation is at the beginning of 2017 (Clean Air Asia, 2016; Wu et al., 2016). For non-road mobile machine, the China III emission standard is schedule to be put into effect in 2016, following the implementation of the China II standard in 2010 (Ministry of Environmental Protection of China, 2014b). China also initiated emission controls for vessels in 2015. "Vessel emission control zones" are required to be set aside in the JJJ region, the YRD region, and the PRD region, and all vessels entering such zones must use low-sulfur fuel (with sulfur content less than or equal to 0.5\%) no later than January 2019 (Ministry of Transport of China, 2015).

However, NMVOC control policies have been evolving very slowly before 2013. Except for the implementation of vehicle standards which removed NMVOC effectively together with other pollutants, national NMVOC control measures or emission standards were limited to fossil-fuel exploitation and distribution and selected solvent products before 2013 (Wang et al., 2014b). In 2015, China launched a comprehensive control program of NMVOC emissions in petrochemical industry, which targeted to 
reduce over 30\% NMVOC emissions from the 2014 levels by 2017 (by 2015 in key metropolitan regions), (Ministry of Environmental Protection of China, 2014a). New emission standards for several industries (petroleum refining, petroleum chemistry, synthetic resin) and a pollution-discharge fee system were developed to facilitate the control measures.

In addition, $80.1 \%$ of collectable agricultural residue were used as fertilizer, feed, or transformed to clean energy in 2015, attaining the $80 \%$ goal of reducing biomass burning (Information office of the Ministry of Agriculture, 2016).

\subsection{Effect of recent control measures on air pollutant emissions and $\mathrm{PM}_{2.5}$} concentrations

\subsubsection{Effect of control measures on air pollutant emissions}

Figure 8 summarizes the recent studies with multiple years $(\geq 3)$ of national emission estimates. In this study, we emphasize on inter-annual emission trends and the effect of control measures; the variability in different emission estimates for a specific year is beyond the focus of this study. In addition, with a focus on the temporal trend in the last decade, we only included studies published in or after 2010.

For $\mathrm{NO}_{\mathrm{x}}$ emissions, the inter-annual trends estimated by different studies agree fairly well with each other. It can be seen that $\mathrm{NO}_{\mathrm{x}}$ emissions were decreasing after 2011 or 2012 owing to the implementation of the $12^{\text {th }}$ Five-Year Plan and the "Action Plan". However, different estimates vary to some extent with respect to the decreasing rate. Xia et al. (2016) developed two parallel emission estimates (PRI and STD) to account for the uncertainty in the penetration and removal efficiency of control technologies. They found that the estimate assuming tighter controls (STD), which derived an $8.9 \%$ decline from 2010 to 2014, was in better agreement with satellite observations. Tsinghua University (Wang et al., 2014b and updates) also got a similar decline rate of 8.6\% during 2010-2014. In addition, the Chinese Academy of Engineering, in cooperation with other institutes, conducted a comprehensive mid-term evaluation of “Action Plan on Prevention and Control of Air Pollution" (Chinese Academy of Engineering, 2016) and estimated that national $\mathrm{NO}_{\mathrm{x}}$ emissions decreased by as large as 19\% during 2013-2015. Based on the analysis above, we conclude that $\mathrm{NO}_{\mathrm{X}}$ emissions are largely reducted during 2011-2015 and the 10\% reduction target set in the $12^{\text {th }}$ Five-Year Plan have been overfulfiled. The deployment of $\mathrm{NO}_{\mathrm{x}}$ removal equipment in power plants and industrial sector is a major contributor to $\mathrm{NO}_{\mathrm{X}}$ emission reduction during this period (Chinese Academy of Engineering, 2016; Xia et al., 2016).

All studies except for EDGAR show that $\mathrm{SO}_{2}$ emissions were increasing until 2006, and then declined ever since. With EDGAR excluded, the decline rates from 2005 to 2010 range 6-15\% among the studies reviewed. Zhang et al. (2015c) applied a structural decomposition analysis and showed that the $\mathrm{SO}_{2}$ reduction during this period mainly resulted from improved technological efficiency, including end-of-pipe abatement efficiency (deployment of flue gas desulfurization facilities) and pollutant generation intensity, while the changes in economic structure did not make noticeable contribution to $\mathrm{SO}_{2}$ reduction. The $\mathrm{SO}_{2}$ reduction rate from 2010 to 2014 was estimated at $12 \%, 2 \%$, and $18 \%$ by Tsinghua University (Wang et al., 2014b and updates), the PRI case of Xia et al. (2016) and the STD case of Xia et al. (2016), respectively. Similar to $\mathrm{NO}_{\mathrm{X}}$, Xia et al. (2016) indicated that satellite observations agreed better with the STD case with larger decline rate. Chinese Academy of Engineering (2016) 
reported a $\mathrm{SO}_{2}$ decreasing rate as high as $29 \%$ for the period of 2013-2015. Therefore, China's $\mathrm{SO}_{2}$ emissions have decreased at a high rate since 2010 , far surpassing the $8 \%$ reduction target of the $12^{\text {th }}$ Five-Year Plan.

As for $\mathrm{PM}_{10}$ and $\mathrm{PM}_{2.5}$, the reviewed studies deviated in terms of the emission trends during 20052008. The emission inventories developed by Chinese institutes (MEIC; Wang et al., 2014b; Zhao et al., 2013f) revealed a declining trend and while those compiled as a part of global or regional inventories showed an increasing trend. We believe that $\mathrm{PM}_{2.5}$ emissions have decreased during 2005-2010 because (1) Chinese domestic estimates took into account more detailed information of control measures; (2) the official statistics showed a 39\% decline in TSP emissions (Chinese Environmental Statistical Bulletin, http://www.mep.gov.cn/zwgk/hjtj/); and (3) air quality simulation using the estimate of Wang et al. (2014b) agreed well with the observed trend in ambient PM $_{10}$ concentrations (Zhao et al., 2013a, b). After 2010, the $\mathrm{PM}_{10}$ and $\mathrm{PM}_{2.5}$ emissions continued to decrease due to a series of control measures described in Section 5.1 especially the release of stringent industrial emission standards. Chinese Academy of Engineering (2016) showed a decline in $\mathrm{PM}_{2.5}$ emissions by $20 \%$ during 2013-2015, as a consequence of the "Action Plan".

All studies show that China's NMVOC emissions increased constantly during 2000-2014 due to inadequate control measures, though the estimated growth rates differ to some extent. However, the implementation of emission standards for vehicles, fuel distribution, and selected solvent products (Section 5.1) have played a role in slowing down the NMVOC emission increase. In particular, the NMVOC emissions from transportation sector have been decreasing since 2005 (Wang et al., 2014b; Wu et al., 2016).

There have been few control measures for $\mathrm{NH}_{3}$ emissions by the end of 2015. All studies reported overall upward trends in $\mathrm{NH}_{3}$ emissions in the last decade except for Kang et al. (2016), which showed that $\mathrm{NH}_{3}$ emissions decreased from 2005 to 2007 and remained roughly constant ever since. This difference arises from different estimation methods, especially the treatment of the types of fertilizer and the corresponding emission factors (Kang et al., 2016), rather than the enforcement of control measures.

Having reviewed the national emission trends, we will further investigate the emission trends in key metropolitan regions. Figure 9 illustrates the emission estimates during 2005-2014 for the whole country, the JJJ region, the YRD region, and the PRD region. We only include the estimates by Wang et al. (2014b) and subsequent updates, and Xia et al. (2016), because these are the only two studies that include multiyear emission estimates until 2014. We adopt the STD case reported by Xia et al. (2016) because it agrees better with the satellite observations compared with the PRI case (Xia et al., 2016). We can see from Figure 9 that the emissions in the three key metropolitan regions generally present similar temporal trends to those of the whole country. Specifically, $\mathrm{NO}_{\mathrm{X}}$ emissions were increasing until about 2011 followed by a subsequent decline; $\mathrm{SO}_{2}$ and $\mathrm{PM}_{2.5}$ emissions were declining while NMVOC emissions were growing in most of 2005-2014. Furthermore, Figure 9 shows that the emissions in the three key metropolitan regions generally increase slower or decrease faster compared with the national emissions, due largely to more stringent control measures in these key regions. This pattern is revealed by both estimates but it is especially pronounced for the estimate of Wang et al. (2014b) and updates. Averaging the two estimates whenever possible, the change rates of $\mathrm{NO}_{\mathrm{X}}$ from 2005 to 2014 are $29 \%,-8 \%, 2 \%$, and $9 \%$ for the whole 
country, the JJJ region, the YRD region, and the PRD region, respectively. The corresponding change rates are $-26 \%,-48 \%,-48 \%$, and $-31 \%$, respectively, for $\mathrm{SO}_{2},-17 \%,-26 \%,-44 \%$, and $-40 \%$, respectively, for $\mathrm{PM}_{2.5}$, and $31 \%, 23 \%, 44 \%$, and $7 \%$, respectively, for NMVOC. The emission trends in the key regions are at least partly responsible for the observed declining trends in $\mathrm{PM}_{2.5}$ concentrations in Beijing, Shanghai, and Guangdong cities (Section 2.2).

\subsubsection{Effect of long-term control measures on $\mathrm{PM}_{2.5}$ concentrations}

In this section, we review the studies which evaluated the effect of long-term control measures (relative to temporary control measures) during 2005-2015 on the changes of $\mathrm{PM}_{2.5}$ concentrations. The reviewed studies are summarized in Table 3.

Wang et al. (2010) evaluated the air quality benefits from $\mathrm{SO}_{2}$ control measures set in China's $11^{\text {th }}$ Five-Year Plan (2006-2010). They estimated that the successful implementation of the national $\mathrm{SO}_{2}$ control policy would reduce total $\mathrm{SO}_{2}$ emissions by as much as $21 \%$ from the 2005 level (52\% from the 2010 business-as-usual scenario, short as "BAU"). Consequently, the annual mean concentrations of $\mathrm{SO}_{4}{ }^{2-}$ and $\mathrm{PM}_{2.5}$ in Eastern China were estimated to decline by 2-16 $\mu \mathrm{g} \mathrm{m}^{-3}(12-40 \%)$ and 3-15 $\mu \mathrm{g} \mathrm{m}^{-3}$ (4$25 \%$ ), respectively, compared with the $2010 \mathrm{BAU}$ scenario. A subsequent post-evaluation presented by Wang et al. (2014a) reported that the $\mathrm{SO}_{2}$ reduction ratio during the $11^{\text {th }}$ Five-Year Plan was about $14 \%$. They calculated that the $\mathrm{SO}_{2}$ reduction decreased ambient $\mathrm{SO}_{4}{ }^{2-}$ concentrations by $8 \%-10 \%$ from the 2005 level in Eastern China. These two studies focused on the air quality benefits achievable from $\mathrm{SO}_{2}$ controls, and they both assumed constant emissions for other air pollutants. Zhao et al. (2013a) assessed the environmental effects of changes of all major air pollutants from 2005 to 2010; the influence of interannual meteorological variability was ruled out by using the same meteorological fields for 2005 and 2010. They concluded that $\mathrm{PM}_{2.5}$ concentrations decreased by $2-17 \mu \mathrm{g} \mathrm{m}^{-3}$ in most of the North China Plain, the YRD region and the PRD region, while increasing by $4.5-16 \mu \mathrm{g} \mathrm{m}^{-3}$ in most of the Sichuan Basin and Hubei Province, as an integrated effect of the decrease in $\mathrm{SO}_{2} / \mathrm{PM}_{2.5}$ emissions and the increase in $\mathrm{NO}_{\mathrm{x}}, \mathrm{NMVOC}$ and $\mathrm{NH}_{3}$ emissions. As an effect solely of emission changes, nitrate concentrations increased across most of Eastern China while sulfate and black carbon concentrations decreased in most of Eastern China, which was consistent with the observational trends described in Section 4.1.

Zhao et al. (2013d) used the WRF/CMAQ model to investigate the impact of planned $\mathrm{NO}_{\mathrm{X}}$ and $\mathrm{SO}_{2}$ control policies in $12^{\text {th }}$ Five-Year Plan on $\mathrm{PM}_{2.5}$ concentrations for the period of 2011-2015. Their simulation revealed that the enforcement of planned control measures could reduce $\mathrm{NO}_{\mathrm{X}}$ and $\mathrm{SO}_{2}$ emissions from the 2010 levels by $12.2 \%$ and $9.6 \%$, respectively (23\% and $19 \%$ from the $2015 \mathrm{BAU}$ scenario, respectively). Under the planned NOx control measures, the annual $\mathrm{PM}_{2.5}$ concentration was expected to decline by $1.5-6 \mu \mathrm{g} \mathrm{m}^{-3}(1.6-8.5 \%)$ in the majority of Eastern China, compared with the 2015 BAU scenario. The corresponding $\mathrm{PM}_{2.5}$ reduction could be $3-8.3 \mu \mathrm{g} \mathrm{m} \mathrm{m}^{-3}$ (3.2-13\%) with the implementation of joint $\mathrm{SO}_{2} / \mathrm{NO}_{\mathrm{X}}$ control measures. Another study using similar method (Wang et al., 2014a) indicated that the $\mathrm{NO}_{\mathrm{X}}$ control measures envisaged in the $12^{\text {th }}$ Five-Year Plan would reduce the $\mathrm{NO}_{3}{ }^{-}$concentration in Eastern China by 3-14\% from 2010 to 2015.

The "Action Plan" required more aggressive control measures and air quality improvement than those set in the $12^{\text {th }}$ Five-Year Plan. As described in Section 5.2.1, Chinese Academy of Engineering 
(2016) comprehensively evaluated the effect of the "Action Plan" by the end of 2015 and concluded that national $\mathrm{SO}_{2}, \mathrm{NO}_{\mathrm{X}}$, and $\mathrm{PM}_{2.5}$ emissions were reduced by as large as $29 \%, 19 \%$, and $22 \%$ during the period of 2013-2015. The emission reductions accounted for a reduction of about $24 \%$ in average $\mathrm{PM}_{2.5}$ concentrations in 74 key cities, implying a high probability for the attainment and even overfulfilment of the air quality target by the end of 2017 for most cities. Facility upgrading in key industries, industrial structure adjustment, pollution control of coal-fired boilers, and control of fugitive dust were identified as the most effect groups of control measures, accounting for $31 \%, 21 \%, 21 \%$, and $15 \%$ of the total $\mathrm{PM}_{2.5}$ concentration reductions, respectively. In contrast, meteorological variability played a negligible role in the improvement of $\mathrm{PM}_{2.5}$ air quality during 2013- 2015.

\subsection{Effect of future control measures on air pollutant emissions and $\mathrm{PM}_{2.5}$} concentrations

\subsubsection{Effect of future control measures on air pollutant emissions}

Many studies have projected future air pollutant emissions considering various control policies. Earlier projections (reported in or before 2008 and based on emissions in or before 2005) generally did not anticipate China's rapid economic growth and stringent control policies in the last decade (Amann et al., 2008; Cofala et al., 2007; Klimont et al., 2001; Klimont et al., 2002; Ohara et al., 2007; Streets and Waldhoff, 2000; van Aardenne et al., 1999). Therefore, these projections usually deviated greatly from the actual emission trends in the last decade (Wang et al., 2014b). To provide an up-to-date evaluation of future emission trends and effects of control policies, we only review emission projections reported after 2008, which are summarized in Figure 10.

For $\mathrm{NO}_{\mathrm{X}}, \mathrm{SO}_{2}$, and $\mathrm{PM}_{2.5}$, Figure 10 presents the results from four studies. Tsinghua University (Wang et al., 2014b; Zhao et al., 2013c) projected emissions for 2020 and 2030 based on the emissions of 2010. They designed two energy paths, a BAU scenario assuming current regulations and implementation status, and a new policy (PC) scenario assuming that stringent energy-saving policies would be released and more tightly enforced. They also designed three emission control strategies including a [0] strategy based on current regulations and implementation status, a [1] strategy assuming new policies to be released progressively, and a [2] strategy which assumed full application of maximum technically feasible control technologies. The combination of energy paths and control strategies yielded six emission scenarios (i.e., BAU[0], BAU[1], BAU[2], PC[0], PC[1], and PC[2]). Similarly, Nanjing University (Zhao et al., 2014) developed three energy paths, i.e., a current policy scenario (CPS), a new policy scenario (NPS), and a stringent 450 scenario (450 S), and three emission control strategies, i.e., a base case (BAS), a reference case (or "best guess" case, REF), and a case which assumed recently issued emission standards were met by all the sources (STD). The energy paths and emission control strategies were coupled to make nine emission scenarios. The International Institute for Applied Systems Analysis (IIASA, Cofala et al., 2012) projected pollutant emissions until 2030 based on 2010 emissions and four scenarios envisaging energy-saving measures at different stringency levels, which the current policy scenario and the $450 \mathrm{ppm}$ scenario being the least and most stringent, respectively. Cai et al. (2016) evaluated the effect of the "Action Plan" on emissions in 2017 and 2020 by assuming that the control measures set in the action plan would be effectively enforced as of 2017 and would be progressively 
strengthened as of 2020 .

With regard to the effect of energy-saving policies, the implementation of aggressive energy paths were expected to decrease $\mathrm{NO}_{\mathrm{X}}$ emissions by $29-35 \%, \mathrm{SO}_{2}$ emissions by $25-36 \%$, and $\mathrm{PM}_{2.5}$ emissions by 11-29\% from the levels of BAU scenario (or current policy scenario, base scenario) in 2030, according to the projections of Tsinghua University (Wang et al., 2014b; Zhao et al., 2013c), Nanjing University and IIASA. Only Tsinghua University (Wang et al., 2014b; Zhao et al., 2013c) and Nanjing University examined the effects of different emission control strategies on future emission trends as of 2030. Since the assumptions underlying their emission control strategies differ, Tsinghua University reported a larger range of emission trajectories than Nanjing University. The fractional differences between the most and least aggressive emission control strategies (coupled with the same energy path) are $72 \%, 57 \%$, and $69 \%$ for $\mathrm{NO}_{\mathrm{X}}, \mathrm{SO}_{2}$, and $\mathrm{PM}_{2.5}$ emissions in 2030, respectively, according to the projection of Tsinghua University. The corresponding fractional differences are $50 \%, 44 \%$, and $31 \%$, respectively, for Nanjing University. Cai et al. (2016) just projected air pollutant emissions as of 2020 but it is the only study that considers the "Action Plan" issued in 2013. Figure 10 illustrates that the change rates of $\mathrm{NO}_{\mathrm{X}}, \mathrm{SO}_{2}$, and $\mathrm{PM}_{2.5}$ emissions during 2010-2020 predicted by Cai et al. (2016) resemble the most aggressive scenario of Nanjing University and the second most aggressive scenario (PC[1]) of Tsinghua University (Wang et al., 2014b; Zhao et al., 2013c), implying the effectiveness of the "Action Plan" in reducing air pollutant emissions if enforced successfully.

For NMVOC, both Tsinghua University (Wang et al., 2014b; Zhao et al., 2013c) and Wei et al. (2011) showed that NMVOC emission would continue to increase under current legislations. It is promising to achieve noticeable emission reduction by 2020 by implementing new control policies. For the year 2020, the PC[1] scenario of Tsinghua University (Wang et al., 2014b; Zhao et al., 2013c), the advanced control measure scenario of Wei et al. (2011) and the "Action Plan" scenario of Cai et al. (2016) all projected a $22-24 \%$ reduction in NMVOC emissions from the 2020 BAU (or current legislation) scenario. Tsinghua University (Wang et al., 2014b; Zhao et al., 2013c) was the only study projecting emissions as of 2030, which illustrated a large reduction potential as much as $64 \%$ from the BAU projection with the enforcement of the most aggressive control measures.

\subsubsection{Effect of future control measures on $\mathrm{PM}_{2.5}$ concentrations}

As described in Section 5.1, the "Action Plan" has played a vital role in China's recent air pollution control activities, and will continue to function until the end of 2017. Cai et al. (2016) evaluated the effect of the "Action Plan" on $\mathrm{PM}_{2.5}$ concentration in the JJ region, the most polluted metropolitan region in China, using the WRF/CMAQ model. They found that the implementation of this plan would lead to larger reduction ratios in the emissions of $\mathrm{SO}_{2}, \mathrm{NO}_{\mathrm{x}}, \mathrm{PM}_{2.5}$, and $\mathrm{NMVOC}(36 \%, 31 \%, 30 \%$, and $12 \%$, respectively) in the JJJ region compared with the national average level. Consequently, the ambient annual $\mathrm{PM}_{2.5}$ concentration in the JJJ region in 2017 was projected to be $28 \%$ lower than those in 2012. With the assumption that the control measures would continue to be strengthened progressively during 2018-2020, the annual $\mathrm{PM}_{2.5}$ concentration in 2020 could be about $38 \%$ lower than that of 2012 . Using a similar method, Jiang et al. (2015b) assessed the air quality improvement achievable under the "Action Plan" in the PRD region from 2012 to 2017. Their results showed that the "Action Plan" could lead to effective emission reductions of $34 \%$ of $\mathrm{SO}_{2}, 28 \%$ of $\mathrm{NO}_{\mathrm{x}}, 26 \%$ of $\mathrm{PM}_{2.5}$, and $10 \%$ of VOCs. These 
emission abatements would lower the $\mathrm{PM}_{2.5}$ concentration by $17 \%$, thereby attaining the $15 \%$ target established in the action plan. It should be noted that Jiang et al. (2015b) assumed that the anthropogenic emissions outside of Guangdong Province would remain constant during the study period. Therefore, larger reduction in $\mathrm{PM}_{2.5}$ concentration might be achieved considering the synergistic control outside Guangdong Province.

An earlier study by Xing et al. (2011) projected the $\mathrm{PM}_{2.5}$ concentrations in 2020 with four scenarios assuming control policies with different levels of stringency using 2005 as the base year. Their reference scenario (the REF[0] scenario) was projected to increase $\mathrm{PM}_{2.5}$ concentrations slightly and their most stringent scenario (the $\mathrm{PC}[2]$ scenario) was estimated to reduce the average $\mathrm{PM}_{2.5}$ concentration in Eastern China from the 2005 level by 16\%, slightly less reduction than those of Cai et al. (2016) and Jiang et al. (2015b). Note that even this most stringent scenario of Xing et al. (2011) did not anticipate the recent stringent control policies released after 2007.

For the mid-term future (as of 2030), Amann et al. (2008), Madaniyazi et al. (2015), and GBD MAPS Working Group (2016) projected the $\mathrm{PM}_{2.5}$ concentrations under various emission scenarios. Amann et al. (2008) used a source-receptor relationship derived from the TM5 model to compute the changes of $\mathrm{PM}_{2.5}$ concentrations in response to emission changes. They found that the $\mathrm{PM}_{2.5}$ concentration would roughly remain the 2005 level under the baseline scenario assuming that existing policies on energy and environment will be continued and implemented. With the uniform application of advanced emission control technologies, the population-weighted $\mathrm{PM}_{2.5}$ concentrations would decline by $44 \%$, from about $80 \mu \mathrm{g} / \mathrm{m}^{3}$ in 2005 to $45 \mu \mathrm{g} / \mathrm{m}^{3}$ in 2030. Similarly, the simulation conducted by Madaniyazi et al. (2015) using a global chemical transport model (MIROC-ESM-CHEM) revealed that $\mathrm{PM}_{2.5}$ concentration in Eastern China would decrease by $0.62 \mu \mathrm{g} / \mathrm{m}^{3}$ under a "current legislation" scenario (CLE) and $20.41 \mu \mathrm{g} / \mathrm{m}^{3}$ under a "maximum technically feasible reduction" scenario (MFR) between 2005 and 2030, respectively. Note that these two projections were based on emission scenarios developed before 2008, which did not anticipate China's rapid economic growth and stringent control policies in the last decade and could affect the projections in both baseline and policy scenarios.

Recently, GBD MAPS Working Group (2016) projected the $\mathrm{PM}_{2.5}$ concentrations in 2030 using the emission scenarios developed by Tsinghua University (Wang et al., 2014b; Zhao et al., 2013c) (see Section 5.3.1 and Figure 10) and subsequently updated based on latest emission estimates in 2011-2013. The results revealed that $\mathrm{PM}_{2.5}$ concentrations would decrease by $2.0-5.1 \mu \mathrm{g} / \mathrm{m}^{3}$ (5-8\%) over four major metropolitan regions (the JJJ region, the YRD region, the PRD region, and the SCB region) from 2013 to 2030 under the BAU[1] scenario assuming current energy policies and progressively strengthened emission control strategies. Under the $\mathrm{PC}[2]$ scenario assuming very stringent energy policies and emission control strategies, the corresponding $\mathrm{PM}_{2.5}$ reduction was estimated to be as high as 14.6-40.3 $\mu \mathrm{g} / \mathrm{m}^{3}$ (40-52\%). Note that $\mathrm{NH}_{3}$ emissions were assumed to remain unchanged in all 2030 scenarios. Further $\mathrm{PM}_{2.5}$ reductions beyond the $\mathrm{PC}[2]$ scenario would be expected if $\mathrm{NH}_{3}$ emissions were significantly reduced.

Wang et al. (2015b) investigated the possible pathways for the attainment of China's new ambient $\mathrm{PM}_{2.5}$ standard ( $35 \mu \mathrm{g} / \mathrm{m}^{3}$ for annual average concentration). They found that the national emissions of $\mathrm{SO}_{2}, \mathrm{NO}_{\mathrm{X}}, \mathrm{PM}_{2.5}$, and $\mathrm{NMVOC}$ should be reduced by at least $51 \%, 64 \%, 53 \%$, and $36 \%$, respectively, 
by 2030 from the 2012 levels, and $\mathrm{NH}_{3}$ emissions should also be reduced slightly. More aggressive control measures are required to be enforced in polluted metropolitan regions. For example, in the JJJ region, emissions of $\mathrm{SO}_{2}, \mathrm{NO}_{\mathrm{x}}, \mathrm{PM}_{2.5}, \mathrm{NMVOC}$, and $\mathrm{NH}_{3}$ need to be cut off by at least $59 \%, 71 \%, 70 \%$, $45 \%$, and $21 \%$, respectively.

To sum up the future $\mathrm{PM}_{2.5}$ projections reviewed above, we conclude that the control policies issued before 2010 are insufficient for notable improvement of $\mathrm{PM}_{2.5}$ air quality. Effective implementation of the "Action Plan" could achieve the planned $\mathrm{PM}_{2.5}$ reduction target, and further control policies in the mid-term (as of 2030) are needed to achieve larger $\mathrm{PM}_{2.5}$ reductions. Due to elevated $\mathrm{PM}_{2.5}$ concentrations nowadays, the attainment of ambient $\mathrm{PM}_{2.5}$ standard would require dramatic reduction of primary $\mathrm{PM}_{2.5}$ and multiple gaseous precursors.

\section{Conclusions and outlook}

This review summarized the spatio-temporal distribution of $\mathrm{PM}_{2.5}$ pollution in China and reviewed the effects of control measures on $\mathrm{PM}_{2.5}$ concentrations.

The annual averaged $\mathrm{PM}_{2.5}$ concentrations in Central-Eastern China were over $100 \mu \mathrm{g} / \mathrm{m}^{3}$, in some regions even over $150 \mu \mathrm{g} / \mathrm{m}^{3}$. In 2013 , only $4.1 \%$ of the cities attained the annual average standard of 35 $\mu \mathrm{g} / \mathrm{m}^{3}$ and much higher than that in Europe. Aitken mode particles tend to dominate the total particle number concentration. Depending on the location and time of the year, NPF has been observed to take place between about 10 and $60 \%$ of the days. SNA ranked the highest fraction among the $\mathrm{PM}_{2.5}$ species, followed by OM, crustal species and EC, which accounted for $6-50 \%, 15-51 \%, 5-41 \%$ and $2-12 \%$, respectively.

In response to serious particulate matter pollution, China has issued a number of aggressive national work plans to improve air quality in the last decade. Owing to the effective implementation of control measures, the national emissions of primary $\mathrm{PM}_{2.5}, \mathrm{SO}_{2}$, and $\mathrm{NO}_{\mathrm{X}}$ have been decreasing since 2005, 2006, and 2011/2012, respectively. Modeling studies showed that the emission control policies implemented in the last decade could result in noticeable reduction in $\mathrm{PM}_{2.5}$ concentrations, contributing to the decreasing trends in observed $\mathrm{PM}_{2.5}$ concentrations in three megacities (Beijing, Shanghai, and Guangzhou). Further control policies in the mid-term (as of 2030) can potentially lead to larger reduction in $\mathrm{PM}_{2.5}$ concentrations. Energy-saving measures and end-of-pipe emission control strategies both have large potentials to reduce air pollutant emissions, therefore they should be applied jointly.

We provide the following recommendations according to the review. First, the observation sites for $\mathrm{PM}_{2.5}$ mass concentration have covered major cities of China, but $\mathrm{PM}_{2.5}$ chemical components were only measured by different institutes with different methods. A $\mathrm{PM}_{2.5}$ component observational network should be established to achieve long-term component measurements with unified methods, which benefits the characteristic analysis and source apportionment of $\mathrm{PM}_{2.5}$ pollution. Second, the release of "Action Plan" marks the transformation from emission-oriented control policies to air quality-oriented control policies and benefits the improvement of $\mathrm{PM}_{2.5}$ air quality in the short term, but no environmental targets or policies have been released beyond 2017. We recommend the government develop a mid-term (as of 2030) ambient $\mathrm{PM}_{2.5}$ target to guide China's future emission control activities. In accordance with the air quality target, provincial and stepped emission reduction targets should be formulated and 
optimized to assure the achievement of the air quality target. Third, while the emissions of $\mathrm{PM}_{2.5}, \mathrm{SO}_{2}$, and $\mathrm{NO}_{\mathrm{X}}$ have started to decline, the emissions of $\mathrm{NMVOC}$ and $\mathrm{NH}_{3}$ have kept increasing or at least remained stable. More ambitious control policies for $\mathrm{NMVOC}$ and $\mathrm{NH}_{3}$ should be gradually enforced to achieve substantial improvement of $\mathrm{PM}_{2.5}$ air quality. Fourth, average $\mathrm{PM}_{2.5}$ concentrations in winter have been remarkably higher than those in summer, and heavy pollution episodes have frequently occurred in winter. Therefore, special control measures are recommended to be applied in winter, e.g., stringent control of heating boilers, prohibition of small stoves, traffic restriction, suspension of some industrial production, etc. Last but not the least, besides the challenge to mitigate particulate matter pollution, China has committed that national $\mathrm{CO}_{2}$ emissions should peak before 2030. In this study we showed that both energy-saving measures and end-of-pipe control measures have large emission reduction potentials as of 2030, while the latter have played a dominant role in the China's historical emission reductions. We suggest that an optimal mix of energy-saving and end-of-pipe control measures should be implemented to maximize the co-benefits between $\mathrm{PM}_{2.5}$ pollution control and climate change mitigation.

\section{Acknoledgements}

This work was supported by the MEP's Special Funds for Research on Public Welfare (201409002), and Strategic Priority Research Program of the Chinese Academy of Sciences (XDB05020300). The authors are grateful to the Australia-China Centre for Air Quality Science and Management (ACCAQSM) for helpful discussions in preparing the manuscript. We also thanks Xuyao Cao, Nianfei Wang,

841 Zhichao Wang from Chongqing Institute of Green and Intelligent Technology, Chinese Academy of Sciences for their help in preparing the draft. 


\section{References}

Amann M., Jiang K. J., Hao J. M., Wang S. X. Scenarios for cost-effective control of air pollution and greenhouse gases in China. International Institute for Applied Systems Analysis, Laxenburg, Austria, 2008, pp. 51.

Andronache C. Estimated variability of below-cloud aerosol removal by rainfall for observed aerosol size distributions. Atmos. Chem. Phys. 2003; 3: 131-143.

Apte J. S., Marshall J. D., Cohen A. J., Brauer M. Addressing Global Mortality from Ambient PM2.5. Environ. Sci. Technol. 2015; 49: 8057-8066.

Asmi A., Wiedensohler A., Laj P., Fjaeraa A. M., Sellegri K., Birmili W., et al. Number size distributions and seasonality of submicron particles in Europe 2008-2009. Atmos. Chem. Phys. 2011; 11: 5505-5538.

Cai S. Y., Wang Y. J., Zhao B., Wang S. X., Chang X., Hao J. M. The impact of the “ Action Plan on Prevention and Control of Air Pollution"'on PM2.5 concentrations in Jing-Jin-Ji region during 2012-2020. Submitted 2016.

Cao J. J., Shen Z. X., Chow J. C., Watson J. G., Lee S. C., Tie X. X., et al. Winter and Summer PM2.5 Chemical Compositions in Fourteen Chinese Cities. Journal of the Air \& Waste Management Association 2012; 62: 1214-1226.

Cao J. J., Zhu C. S., Tie X. X., Geng F. H., Xu H. M., Ho S. S. H., et al. Characteristics and sources of carbonaceous aerosols from Shanghai, China. Atmos. Chem. Phys. 2013; 13: 803-817.

Chan C. K., Yao X. Air pollution in mega cities in China. Atmos. Environ. 2008; 42: 1-42.

Chang W., Liao H., Wang H. Climate responses to direct radiative forcing of anthropogenic aerosols, tropospheric ozone, and long-lived greenhouse gases in eastern China over 1951-2000. Adv. Atmos. Sci. 2009; 26 : 748-762.

Chen Y., Schleicher N., Chen Y., Chai F., Norra S. The influence of governmental mitigation measures on contamination characteristics of PM2.5 in Beijing. Sci. Total Environ. 2014; 490: 647-658.

Cheng Z., Wang S., Fu X., Watson J. G., Jiang J., Fu Q., et al. Impact of biomass burning on haze pollution in the Yangtze River delta, China: a case study in summer 2011. Atmos. Chem. Phys. 2014; 14: 45734585.

Cheng Z., Wang S. X., Jiang J. K., Fu Q. Y., Chen C. H., Xu B. Y., et al. Long-term trend of haze pollution and impact of particulate matter in the Yangtze River Delta, China. Environ. Pollut. 2013; 182: 101-110.

China National Coal Association. Bulletin for the reform and development of China's coal industry in 2015, 2016.

Chinese Academy of Engineering. Report on mid-term evaluation of the Action Plan on Prevention and Control of Air Pollution. Chinese Academy of Engineering, Beijing, China, 2016.

Clean Air Asia. China Air 2015: Air Pollution Prevention and Control Progress in Chinese Cities, available at http://www.allaboutair.cn/a/cbw/bg/2015/1116/90.html. Beijing, China, 2015.

Clean Air Asia. China Air 2016: Air Pollution Prevention and Control Progress in Chinese Cities, available at http://www.allaboutair.cn/a/cbw/bg/2016/0822/472.html. Beijing, China, 2016.

Cofala J., Amann M., Klimont Z., Kupiainen K., Hoglund-Isaksson L. Scenarios of global anthropogenic emissions of air pollutants and methane until 2030. Atmos Environ 2007; 41: 8486-8499.

Cofala J., Bertok I., Borken-Kleefeld J., Heyes C., Klimont Z., Rafaj P., et al. Emissions of Air Pollutants for the World Energy Outlook 2012 Energy Scenarios. International Institute for Applied Systems Analysis, Laxenburg, Austria, 2012.

Dan M., Zhuang G. S., Li X. X., Tao H. R., Zhuang Y. H. The characteristics of carbonaceous species and their sources in PM2.5 in Beijing. Atmos. Environ. 2004; 38: 3443-3452.

Du H. H., Kong L. D., Cheng T. T., Chen J. M., Du J. F., Li L., et al. Insights into summertime haze pollution events over Shanghai based on online water-soluble ionic composition of aerosols. Atmos. Environ. 2011; 45: 5131-5137. 
Duan F. K., He K. B., Ma Y. L., Yang F. M., Yu X. C., Cadle S. H., et al. Concentration and chemical characteristics of PM2.5 in Beijing, China: 2001-2002. Sci. Total Environ. 2006; 355: 264-275.

Feng J., Chan C. K., Fang M., Hu M., He L., Tang X. Impact of meteorology and energy structure on solvent extractable organic compounds of PM 2.5 in Beijing, China. Chemosphere 2005; 61: 623-632.

Feng J., Chan C. K., Fang M., Hu M., He L., Tang X. Characteristics of organic matter in PM 2.5 in Shanghai. Chemosphere 2006a; 64: 1393-400.

Feng J., Hu J., Xu B., Hu X., Sun P., Han W., et al. Characteristics and seasonal variation of organic matter in PM 2.5 at a regional background site of the Yangtze River Delta region, China. Atmos. Environ. 2015a; 123: 288-297.

Feng J., Hu M., Chan C. K., Lau P. S., Fang M., He L., et al. A comparative study of the organic matter in PM 2.5 from three Chinese megacities in three different climatic zones. Atmos. Environ. 2006b; 40: 3983-3994.

Feng J., Sun P., Hu X., Zhao W., Wu M., Fu J. The chemical composition and sources of PM 2.5 during the 2009 Chinese New Year's holiday in Shanghai. Atmos. Res. 2012a; 118: 435-444.

Feng J. L., Guo Z. G., Chan C. K., Fang M. Properties of organic matter in PM2.5 at Changdao Island, China - A rural site in the transport path of the Asian continental outflow. Atmos. Environ. 2007; 41: 1924-1935.

Feng J. L., Hu J. C., Xu B. H., Hu X. L., Sun P., Han W. L., et al. Characteristics and seasonal variation of organic matter in PM2.5 at a regional background site of the Yangtze River Delta region, China. Atmos. Environ. 2015b; 123: 288-297.

Feng J. L., Sun P., Hu X. L., Zhao W., Wu M. H., Fu J. M. The chemical composition and sources of PM2.5 during the 2009 Chinese New Year's holiday in Shanghai. Atmos. Res. 2012b; 118: 435-444.

Feng Y. L., Chen Y. J., Guo H., Zhi G. R., Xiong S. C., Li J., et al. Characteristics of organic and elemental carbon in PM2.5 samples in Shanghai, China. Atmos. Res. 2009; 92: 434-442.

Fu P. Q., Kawamura K., Chen J., Li J., Sun Y. L., Liu Y., et al. Diurnal variations of organic molecular tracers and stable carbon isotopic composition in atmospheric aerosols over Mt. Tai in the North China Plain: an influence of biomass burning. Atmospheric Chemistry \& Physics 2012; 12: 8359-8375.

GBD MAPS Working Group. Burden of disease attributable to coal-burning and other major sources of air pollution in China. Special Report 20, available at https://www.healtheffects.org/publication/burdendisease-attributable-coal-burning-and-other-air-pollution-sources-china. Health Effects Institute, Boston, MA, 2016.

Grimm H., Eatough D. J. Aerosol Measurement: The Use of Optical Light Scattering for the Determination of Particulate Size Distribution, and Particulate Mass, Including the Semi-Volatile Fraction. Journal of the Air \& Waste Management Association 2009; 59: 101-107.

Gu Z. P., Feng J. L., Han W. L., Wu M. H., Fu J. M., Sheng G. Y. Characteristics of organic matter in PM2.5 from an e-waste dismantling area in Taizhou, China. Chemosphere 2010; 80: 800-806.

Guo S., Hu M., Zamora M. L., Peng J. F., Shang D. J., Zheng J., et al. Elucidating severe urban haze formation in China. PNAS 2014; 111: 17373-17378.

Guo W. The Ministry of Environmental Protection released six new emission standards, 2015.

Guo Z. G., Sheng L. F., Feng J. L., Fang M. Seasonal variation of solvent extractable organic compounds in the aerosols in Qingdao, China. Atmos. Environ. 2003; 37: 1825-1834.

Han L. H., Zhuang G. S., Yele S., Wang Z. F. Local and non-local sources of airborne particulate pollution at Beijing. Science in China Series B-Chemistry 2005; 48: 253-264.

Hansen J. C., Woolwine Iii W. R., Bates B. L., Clark J. M., Kuprov R. Y., Mukherjee P., et al. Semicontinuous PM2.5 and PM10 Mass and Composition Measurements in Lindon, Utah, during Winter 2007. Journal of the Air \& Waste Management Association 2010; 60: 346-355.

He K. B., Yang F. M., Ma Y. L., Zhang Q., Yao X. H., Chan C. K., et al. The characteristics of PM2.5 in Beijing, China. Atmos. Environ. 2001; 35: 4959-4970.

Hofman J., Staelens J., Cordell R., Stroobants C., Zikova N., Hama S. M. L., et al. Ultrafine particles in 
four European urban environments: Results from a new continuous long-term monitoring network. Atmos. Environ. 2016; 136: 68-81.

Huang K., Zhuang G., Lin Y., Fu J. S., Wang Q., Liu T., et al. Typical types and formation mechanisms of haze in an Eastern Asia megacity, Shanghai. Atmos. Chem. Phys. 2012a; 12: 105-124.

Huang X.-F., Chen D.-L., Lan Z.-J., Feng N., He L.-Y., Yu G.-H., et al. Characterization of organic aerosol in fine particles in a mega-city of South China: Molecular composition, seasonal variation, and size distribution. Atmos. Res. 2012b; 114-115: 28-37.

Huang X. F., He L. Y., Hu M., Zhang Y. H. Annual variation of particulate organic compounds in PM2.5 in the urban atmosphere of Beijing. Atmos. Environ. 2006; 40: 2449-2458.

Information office of the Ministry of Agriculture. The comprehensive utilization rate of agricultural residue exceeds $80 \%$ in China, 2016.

Jiang J. K., Zhou W., Cheng Z., Wang S. X., He K. B., Hao J. M. Particulate Matter Distributions in China during a Winter Period with Frequent Pollution Episodes (January 2013). Aerosol and Air Quality Research 2015a; 15: 494-U157.

Jiang X. J., Hong C. P., Zheng Y. X., Zheng B., Guan D. B., Gouldson A., et al. To what extent can China's near-term air pollution control policy protect air quality and human health? A case study of the Pearl River Delta region. Environ Res Lett 2015b; 10.

Jung J., Lee H., Kim Y. J., Liu X. G., Zhang Y. H., Hu M., et al. Optical properties of atmospheric aerosols obtained by in situ and remote measurements during 2006 Campaign of Air Quality Research in Beijing (CAREBeijing-2006). Journal of Geophysical Research-Atmospheres 2009; 114.

Kan H. D., London S. J., Chen G. H., Zhang Y. H., Song G. X., Zhao N. Q., et al. Differentiating the effects of fine and coarse particles on daily mortality in Shanghai, China. Environ. Int. 2007; 33: 376384.

Kang Y. N., Liu M. X., Song Y., Huang X., Yao H., Cai X. H., et al. High-resolution ammonia emissions inventories in China from 1980 to 2012. Atmos Chem Phys 2016; 16: 2043-2058.

Kerminen V. M., Paramonov M., Anttila T., Riipinen I., Fountoukis C., Korhonen H., et al. Cloud condensation nuclei production associated with atmospheric nucleation: a synthesis based on existing literature and new results. Atmos. Chem. Phys. 2012; 12: 12037-12059.

Kivekäs N., Sun J., Zhan M., Kerminen V. M., Hyvärinen A., Komppula M., et al. Long term particle size distribution measurements at Mount Waliguan, a high-altitude site in inland China. Atmos. Chem. Phys. 2009; 9: 5461-5474.

Klimont Z., Cofala J., Schopp W., Amann M., Streets D. G., Ichikawa Y., et al. Projections of SO2, NOx, NH3 and VOC emissions in East Asia up to 2030. Water Air Soil Poll 2001; 130: 193-198.

Klimont Z., Streets D. G., Gupta S., Cofala J., Fu L. X., Ichikawa Y. Anthropogenic emissions of nonmethane volatile organic compounds in China. Atmos Environ 2002; 36: 1309-1322.

Kulmala M., Luoma K., Virkkula A., Petäjä T., Paasonen P., Kerminen V. M., et al. On the modesegregated aerosol particle number concentration load: Contributions of primary and secondary particles in Hyytiälä and Nanjing. 2016a.

Kulmala M., Petäjä T., Kerminen V.-M., Kujansuu J., Ruuskanen T., Ding A., et al. On secondary new particle formation in China. Frontiers of Environmental Science \& Engineering 2016b; 10: 1-10.

Li X. R., Wang Y. S., Guo X. Q., Wang Y. F. Seasonal variation and source apportionment of organic and inorganic compounds in PM2.5 and PM10 particulates in Beijing, China. Journal of Environmental Sciences 2013; 25: 741-750.

Lim S. S., Vos T., Flaxman A. D., Danaei G., Shibuya K., Adair-Rohani H., et al. A comparative risk assessment of burden of disease and injury attributable to 67 risk factors and risk factor clusters in 21 regions, 1990-2010: a systematic analysis for the Global Burden of Disease Study 2010. The Lancet 2012; 380: 2224-2260.

Lin P., Hu M., Deng Z., Slanina J., Han S., Kondo Y., et al. Seasonal and diurnal variations of organic carbon in PM2.5 in Beijing and the estimation of secondary organic carbon. Journal of Geophysical Research-Atmospheres 2009; 114. 
Ling X. L., Guo W. D., Fu C. B. Composite analysis of impacts of dust aerosols on surface atmospheric variables and energy budgets in a semiarid region of China. Journal of Geophysical ResearchAtmospheres 2014; 119: 3107-3123.

Liu Z., Hu B., Zhang J., Yu Y., Wang Y. Characteristics of aerosol size distributions and chemical compositions during wintertime pollution episodes in Beijing. Atmos. Res. 2016a; 168: 1-12.

Liu Z., Wang Y., Hu B., Ji D., Zhang J., Wu F., et al. Source appointment of fine particle number and volume concentration during severe haze pollution in Beijing in January 2013. Environmental Science and Pollution Research 2016b; 23: 6845-6860.

Ma N., Birmili W. Estimating the contribution of photochemical particle formation to ultrafine particle number averages in an urban atmosphere. Sci. Total Environ. 2015; 512-513: 154-166.

Madaniyazi L., Nagashima T., Guo Y. M., Yu W. W., Tong S. L. Projecting Fine Particulate MatterRelated Mortality in East China. Environ Sci Technol 2015; 49: 11141-11150.

Martini F. M. S., Hasenkopf C. A., Roberts D. C. Statistical analysis of PM2.5 observations from diplomatic facilities in China. Atmos. Environ. 2015; 110: 174-185.

Ministry of Environmental Protection of China. Comprehensive control plan for volatile organic compounds from the petrochemical industry, 2014a.

Ministry of Environmental Protection of China. Limits and measurement methods for exhaust pollutants from diesel engines of non-road mobile machinery (China III, IV). Beijing, China: China Environmental Science Press, 2014b.

Ministry of Environmental Protection of China. The State Council sets target for the elimination of Yellow Label vehicles and old vehicles in 2014, 2014c.

Ministry of Environmental Protection of China. The Ministry of Environmental Protection reports the progress in the elimination of Yellow Label vehicles during January-November, 2015, 2015a.

Ministry of Environmental Protection of China. Work plan for ultralow emission and energy saving retrofit of coal-fired power plants, $2015 \mathrm{~b}$.

Ministry of Environmental Protection of China. Record of the press conference of China's minister of environmental protection, Chen Jining, hosted by the Information Office of the State Council, 2016.

Ministry of Industry and Information Technology of China. Bulletin NO. 27 of the Ministry of Industry and Information Technology of China, 2014.

Ministry of Transport of China. Work plan for "vessel emission control zone" in the Pearl River Delta region, the Yangtze River Delta region, and the Bohai Rim region (the Jing-Jin-Ji region), 2015.

National Bureau of Statistics. China Energy Statistical Yearbook 2011. Beijing: China Statistics Press, 2011.

National Bureau of Statistics. Statistical Communique of the People's Republic of China on the 2015 National Economic and Social Development, available at http://www.stats.gov.cn/tjsj/zxfb/201602/t20160229_1323991.html, 2016.

Nie W., Ding A., Wang T., Kerminen V.-M., George C., Xue L., et al. Polluted dust promotes new particle formation and growth. Scientific Reports 2014; 4: 6634.

Ohara T., Akimoto H., Kurokawa J., Horii N., Yamaji K., Yan X., et al. An Asian emission inventory of anthropogenic emission sources for the period 1980-2020. Atmos Chem Phys 2007; 7: 4419-4444.

Paasonen P., Kupiainen K., Klimont Z., Visschedijk A., Denier van der Gon H. A. C., Amann M. Continental anthropogenic primary particle number emissions. Atmos. Chem. Phys. 2016; 16: 6823-6840.

Peng J., Chen S., Lu H. L., Liu Y. X., Wu J. S. Spatiotemporal patterns of remotely sensed PM2.5 concentration in China from 1999 to 2011. Remote Sens. Environ. 2016; 174: 109-121.

Peng J. F., Hu M., Wang Z. B., Huang X. F., Kumar P., Wu Z. J., et al. Submicron aerosols at thirteen diversified sites in China: size distribution, new particle formation and corresponding contribution to cloud condensation nuclei production. Atmos. Chem. Phys. 2014; 14: 10249-10265.

Putaud J. P., Van Dingenen R., Alastuey A., Bauer H., Birmili W., Cyrys J., et al. A European aerosol 
phenomenology - 3: Physical and chemical characteristics of particulate matter from 60 rural, urban, and kerbside sites across Europe. Atmos. Environ. 2010; 44: 1308-1320.

Qi X. M., Ding A. J., Nie W., Petäjä T., Kerminen V. M., Herrmann E., et al. Aerosol size distribution and new particle formation in the western Yangtze River Delta of China: 2 years of measurements at the SORPES station. Atmos. Chem. Phys. 2015; 15: 12445-12464.

Qu W. J., Arimoto R., Zhang X. Y., Zhao C. H., Wang Y. Q., Sheng L. F., et al. Spatial distribution and interannual variation of surface PM10 concentrations over eighty-six Chinese cities. Atmos. Chem. Phys. 2010; 10: 5641-5662.

Raes F., Dingenen R. V., Vignati E., Wilson J., Putaud J.-P., Seinfeld J. H., et al. Formation and cycling of aerosols in the global troposphere. Atmos. Environ. 2000; 34: 4215-4240.

Raes F., Liao H., Chen W.-T., Seinfeld J. H. Atmospheric chemistry-climate feedbacks. Journal of Geophysical Research: Atmospheres 2010; 115: n/a-n/a.

Rodríguez S., Cuevas E. The contributions of "minimum primary emissions" and "new particle formation enhancements" to the particle number concentration in urban air. J. Aerosol Sci 2007; 38: 1207-1219.

Schleicher N., Norra S., Chai F., Chen Y., Wang S., Stüben D. Seasonal Trend of Water-Soluble Ions at One TSP and Five PM2.5 Sampling Sites in Beijing, China. In: Rauch S, Morrison GM, Monzón A, editors. Highway and Urban Environment: Proceedings of the 9th Highway and Urban Environment symposium. Springer Netherlands, Dordrecht, 2010, pp. 87-95.

Sciare J., Cachier H., Sarda-Estève R., Yu T., Wang X. Semi-volatile aerosols in Beijing (R.P. China): Characterization and influence on various PM2.5 measurements. Journal of Geophysical Research: Atmospheres 2007; 112: n/a-n/a.

Shen X., Sun J., Zhang X., Zhang Y., Zhang L., Fan R. Key features of new particle formation events at background sites in China and their influence on cloud condensation nuclei. Frontiers of Environmental Science \& Engineering 2016a; 10: 1-11.

Shen X. J., Sun J. Y., Zhang X. Y., Kivekas N., Zhang Y. M., Wang T. T., et al. Particle Climatology in Central East China Retrieved from Measurements in Planetary Boundary Layer and in Free Troposphere at a 1500-m-High Mountaintop Site. Aerosol and Air Quality Research 2016b; 16: 689-701.

Shen X. J., Sun J. Y., Zhang Y. M., Wehner B., Nowak A., Tuch T., et al. First long-term study of particle number size distributions and new particle formation events of regional aerosol in the North China Plain. Atmos. Chem. Phys. 2011; 11: 1565-1580.

Shi Z. B., Shao L. Y., Jones T. P., Whittaker A. G., Lu S. L., Berube K. A., et al. Characterization of airborne individual particles collected in an urban area, a satellite city and a clean air area in Beijing, 2001. Atmos. Environ. 2003; 37: 4097-4108.

Sin D. W. M., Fung W. H., Choi Y. Y., Lam C. H., Louie P. K. K., Chow J. C., et al. Seasonal and spatial variation of solvent extractable organic compounds in fine suspended particulate matter in Hong Kong. J Air Waste Manag Assoc 2005; 55: 291-301.

Song S. J., Wu Y., Jiang J. K., Yang L., Cheng Y., Hao J. M. Chemical characteristics of size-resolved PM2.5 at a roadside environment in Beijing, China. Environ. Pollut. 2012; 161: 215-221.

Sparmacher H., Fülber K., Bonka H. Below-cloud scavenging of aerosol particles: Particle-bound radionuclides_Experimental. Atmospheric Environment.part A.general Topics 1993; 27: 605-618.

Streets D. G., Waldhoff S. T. Present and future emissions of air pollutants in China: SO2, NOx, and CO. Atmos Environ 2000; 34: 363-374.

Sun Y., Zhuang G. S., Yuan H., Zhang X. Y., Guo J. H. Characteristics and sources of 2002 super dust storm in Beijing. Chin. Sci. Bull. 2004; 49: 698-705.

Tan J.-h., Duan J.-c., Chai F.-h., He K.-b., Hao J.-M. Source apportionment of size segregated fine/ultrafine particle by PMF in Beijing. Atmos. Res. 2014; 139: 90-100.

The State Council of the People's Republic of China. The Twelfth Five-Year Plan for Environmental Protection, 2011.

The State Council of the People's Republic of China. Notice to issue the "Action Plan on Prevention and Control of Air Pollution", 2013. 
van Aardenne J. A., Carmichael G. R., Levy H., Streets D., Hordijk L. Anthropogenic NOx emissions in Asia in the period 1990-2020. Atmos Environ 1999; 33: 633-646.

van Donkelaar A., Martin R. V., Brauer M., Boys B. L. Use of satellite observations for long-term exposure assessment of global concentrations of fine particulate matter. Environmental health perspectives 2015; 123: 135.

Wang G., Kawamura K., Lee S., Ho K., Cao J. Molecular, Seasonal, and Spatial Distributions of Organic Aerosols from Fourteen Chinese Cities. Environmental Science \& Technology 2006a; 40: 4619-4625.

Wang H. L., Qiao L. P., Lou S. R., Zhou M., Ding A. J., Huang H. Y., et al. Chemical composition of PM2.5 and meteorological impact among three years in urban Shanghai, China. Journal of Cleaner Production 2016; 112: 1302-1311.

Wang H. L., Zhu B., Shen L. J., Xu H. H., An J. L., Xue G. Q., et al. Water-soluble ions in atmospheric aerosols measured in five sites in the Yangtze River Delta, China: Size-fractionated, seasonal variations and sources. Atmos. Environ. 2015a; 123: 370-379.

Wang L. T., Jang C., Zhang Y., Wang K., Zhang Q. A., Streets D., et al. Assessment of air quality benefits from national air pollution control policies in China. Part II: Evaluation of air quality predictions and air quality benefits assessment. Atmos Environ 2010; 44: 3449-3457.

Wang Q., Shao M., Zhang Y., Wei Y., Hu M., Guo S. Source apportionment of fine organic aerosols in Beijing. Atmos. Chem. Phys. 2009; 9: 8573-8585.

Wang S. X., Hao J. M. Air quality management in China: Issues, challenges, and options. J Environ SciChina 2012; 24: 2-13.

Wang S. X., Xing J., Zhao B., Jang C., Hao J. M. Effectiveness of national air pollution control policies on the air quality in metropolitan areas of China. J Environ Sci-China 2014a; 26: 13-22.

Wang S. X., Zhao B., Cai S. Y., Klimont Z., Nielsen C. P., Morikawa T., et al. Emission trends and mitigation options for air pollutants in East Asia. Atmos Chem Phys 2014b; 14: 6571-6603.

Wang S. X., Zhao B., Wu Y., Hao J. M. Target and measures to prevent and control ambient fine particle pollution in China. Chinese Journal of Environmental Management 2015b: 37-43.

Wang Y., Zhuang G. S., Chen S., An Z. S., Zheng A. H. Characteristics and sources of formic, acetic and oxalic acids in PM2.5 and PM10 aerosols in Beijing, China. Atmos. Res. 2007; 84: 169-181.

Wang Y., Zhuang G. S., Tang A. H., Yuan H., Sun Y. L., Chen S. A., et al. The ion chemistry and the source of PM2.5 aerosol in Beijing. Atmos. Environ. 2005; 39: 3771-3784.

Wang Y., Zhuang G. S., Zhang X. Y., Huang K., Xu C., Tang A. H., et al. The ion chemistry, seasonal cycle, and sources of PM2.5 and TSP aerosol in Shanghai. Atmos. Environ. 2006b; 40: 2935-2952.

Wang Y. Q., Zhang X. Y., Sun J. Y., Zhang X. C., Che H. Z., Li Y. Spatial and temporal variations of the concentrations of PM10, PM2.5 and PM1 in China. Atmos. Chem. Phys. 2015c; 15: 13585-13598.

Wang Z. B., Hu M., Sun J. Y., Wu Z. J., Yue D. L., Shen X. J., et al. Characteristics of regional new particle formation in urban and regional background environments in the North China Plain. Atmos. Chem. Phys. 2013a; 13: 12495-12506.

Wang Z. B., Hu M., Wu Z. J., Yue D. L., He L. Y., Huang X. F., et al. Long-term measurements of particle number size distributions and the relationships with air mass history and source apportionment in the summer of Beijing. Atmos. Chem. Phys. 2013b; 13: 10159-10170.

Wang Z. B., Hu M., Yue D. L., He L. Y. New particle formation in the presence of a strong biomass burning episode at a downwind rural site in PRD, China. Tellus B 2013c.

Wei W., Wang S. X., Hao J. M., Cheng S. Y. Projection of anthropogenic volatile organic compounds (VOCs) emissions in China for the period 2010-2020. Atmos Environ 2011; 45: 6863-6871.

Wiedensohler A., Cheng Y. F., Nowak A., Wehner B., Achtert P., Berghof M., et al. Rapid aerosol particle growth and increase of cloud condensation nucleus activity by secondary aerosol formation and condensation: A case study for regional air pollution in northeastern China. Journal of Geophysical Research: Atmospheres 2009; 114: D00G08.

Williams J., de Reus M., Krejci R., Fischer H., Ström J. Application of the variability-size relationship 
to atmospheric aerosol studies: estimating aerosol lifetimes and ages. Atmos. Chem. Phys. 2002; 2: 133 145.

Wu Y., Zhang S. J., Hao J. M., Liu H., Wu X. M., Hu J. N., et al. On-road vehicle emissions and their control in China: A review and outlook. Science of the Total Environment 2016.

Wu Z., Hu M., Lin P., Liu S., Wehner B., Wiedensohler A. Particle number size distribution in the urban atmosphere of Beijing, China. Atmos. Environ. 2008; 42: 7967-7980.

Xia Y. M., Zhao Y., Nielsen C. P. Benefits of of China's efforts in gaseous pollutant control indicated by the bottom-up emissions and satellite observations 2000-2014. Atmos Environ 2016; 136: 43-53.

Xiao S., Wang M. Y., Yao L., Kulmala M., Zhou B., Yang X., et al. Strong atmospheric new particle formation in winter in urban Shanghai, China. Atmos. Chem. Phys. 2015; 15: 1769-1781.

Xing J., Wang S. X., Chatani S., Zhang C. Y., Wei W., Hao J. M., et al. Projections of air pollutant emissions and its impacts on regional air quality in China in 2020. Atmos Chem Phys 2011; 11: 31193136.

Xu J., Bergin M. H., Yu X., Liu G., Zhao J., Carrico C. M., et al. Measurement of aerosol chemical, physical and radiative properties in the Yangtze delta region of China. Atmos. Environ. 2002; 36: 161173.

Yang F., Huang L., Duan F., Zhang W., He K., Ma Y., et al. Carbonaceous species in PM2.5 at a pair of rural/urban sites in Beijing, 2005-2008. Atmos. Chem. Phys. 2011a; 11: 7893-7903.

Yang F., Tan J., Zhao Q., Du Z., He K., Ma Y., et al. Characteristics of PM2.5 speciation in representative megacities and across China. Atmos. Chem. Phys. 2011b; 11: 5207-5219.

Yang L. I. The space-time variations of PM10 concentration in major cities of China during 2000-2007. Journal of Arid Land Resources \& Environment 2009.

Yu L., Wang G., Zhang R., Zhang L., Song Y., Wu B., et al. Characterization and Source Apportionment of PM2.5 in an Urban Environment in Beijing. Aerosol and Air Quality Research 2013; 13: 574-583.

Yu M., Carmichael G. R., Zhu T., Cheng Y. F. Sensitivity of predicted pollutant levels to anthropogenic heat emissions in Beijing. Atmos. Environ. 2014; 89: 169-178.

Zhang D., Wang X., Liu B., Tian C., Shi A., Zhou J., et al. Characteristics of PM (2.5) and Its Chemical Composition in the Urban Area of Beijing. Research of Environmental Sciences 2015a.

Zhang L., Liao H., Li J. Impacts of Asian summer monsoon on seasonal and interannual variations of aerosols over eastern China. J. Geophys. Res. 2010; 115.

Zhang Q. Y., Yan R. C., Fan J. W., Yu S. C., Yang W. D., Li P. F., et al. A Heavy Haze Episode in Shanghai in December of 2013: Characteristics, Origins and Implications. Aerosol and Air Quality Research 2015b; 15: 1881-1893.

Zhang R., Jing J., Tao J., Hsu S. C., Wang G., Cao J., et al. Chemical characterization and source apportionment of PM2.5 in Beijing: seasonal perspective. Atmos. Chem. Phys. 2013; 13: 7053-7074.

Zhang W., Wang J. N., Zhang B., Bi J., Jiang H. Q. Can China Comply with Its 12th Five-Year Plan on Industrial Emissions Control: A Structural Decomposition Analysis. Environ Sci Technol 2015c; 49: 4816-4824.

Zhang X. Y., Wang J. Z., Wang Y. Q., Liu H. L., Sun J. Y., Zhang Y. M. Changes in chemical components of aerosol particles in different haze regions in China from 2006 to 2013 and contribution of meteorological factors. Atmos. Chem. Phys. 2015d; 15: 12935-12952.

Zhang X. Y., Wang Y. Q., Niu T., Zhang X. C., Gong S. L., Zhang Y. M., et al. Atmospheric aerosol compositions in China: spatial/temporal variability, chemical signature, regional haze distribution and comparisons with global aerosols. Atmos. Chem. Phys. 2012; 11: 26571-26615.

Zhao B., Wang S. X., Dong X. Y., Wang J. D., Duan L., Fu X., et al. Environmental effects of the recent emission changes in China: implications for particulate matter pollution and soil acidification. Environ. Res. Lett. 2013a; 8.

Zhao B., Wang S. X., Dong X. Y., Wang J. D., Duan L., Fu X., et al. Environmental effects of the recent emission changes in China: implications for particulate matter pollution and soil acidification. Environ 
Res Lett 2013b; 8: 024031.

Zhao B., Wang S. X., Liu H., Xu J. Y., Fu K., Klimont Z., et al. NOx emissions in China: historical trends and future perspectives. Atmos Chem Phys 2013c; 13: 9869-9897.

1190 Zhao B., Wang S. X., Wang J. D., Fu J. S., Liu T. H., Xu J. Y., et al. Impact of national NOx and SO2 control policies on particulate matter pollution in China. Atmos Environ 2013d; 77: 453-463.

Zhao M. F., Huang Z. S., Qiao T., Zhang Y. K., Xiu G. L., Yu J. Z. Chemical characterization, the transport pathways and potential sources of PM2.5 in Shanghai: Seasonal variations. Atmos. Res. 2015a; 158: 6678.

Zhao P. S., Dong F., He D., Zhao X. J., Zhang X. L., Zhang W. Z., et al. Characteristics of concentrations and chemical compositions for PM2.5 in the region of Beijing, Tianjin, and Hebei, China. Atmos. Chem. Phys. 2013e; 13: 4631-4644.

1198 Zhao S., Yu Y., Yin D., He J. Meteorological dependence of particle number concentrations in an urban area of complex terrain, Northwestern China. Atmos. Res. 2015b; 164-165: 304-317.

Zhao X., Zhang X., Xu X., Xu J., Meng W., Pu W. Seasonal and diurnal variations of ambient PM2.5 concentration in urban and rural environments in Beijing. Atmos. Environ. 2009; 43: 2893-2900.

Zhao X. J., Zhang X. L., Pu W. W., Meng W., Xu X. F. Scattering properties of the atmospheric aerosol in Beijing, China. Atmos. Res. 2011; 101: 799-808.

Zhao Y., Zhang J., Nielsen C. P. The effects of recent control policies on trends in emissions of anthropogenic atmospheric pollutants and CO2 in China. Atmos Chem Phys 2013f; 13: 487-508.

1206

1207

Zhao Y., Zhang J., Nielsen C. P. The effects of energy paths and emission controls and standards on future trends in China's emissions of primary air pollutants. Atmos Chem Phys 2014; 14: 8849-8868.

1208

1209

1210

Zheng G. J., Duan F. K., Ma Y. L., Zhang Q., Huang T., Kimoto T., et al. Episode-Based Evolution Pattern Analysis of Haze Pollution: Method Development and Results from Beijing, China. Environmental Science \& Technology 2016; 50: 4632-4641.

1211

1212

Zhu J., Liao H., Li J. Increases in aerosol concentrations over eastern China due to the decadal-scale weakening of the East Asian summer monsoon. Geophys. Res. Lett. 2012; 39: L09809. 
1216 the scientific literature. Only the data sets covering a full year of measurements are included. The

1217 numbers refer to the mean concentration measured at each site and given size range.

\begin{tabular}{|c|c|c|c|c|c|c|}
\hline \multirow{2}{*}{$\begin{array}{l}\text { Site Description } \\
\begin{array}{l}\text { Beijing, } \\
\text { urban }\end{array}\end{array}$} & \multirow{2}{*}{$\begin{array}{l}\begin{array}{l}\text { Study } \\
\text { period }\end{array} \\
2004.03- \\
2006.02\end{array}$} & \multicolumn{4}{|c|}{$\begin{array}{l}\text { Average particle number concentrations }\left(\mathrm{cm}^{-3}\right) \text { in different size } \\
\text { ranges, and the total concentration }\end{array}$} & \multirow{2}{*}{$\begin{array}{l}\text { Reference } \\
\mathrm{Wu} \text { et al. } \\
(2008)\end{array}$} \\
\hline & & $\begin{array}{l}3-20 \mathrm{~nm} \\
9000\end{array}$ & $\begin{array}{l}20-100 \mathrm{~nm} \\
15900\end{array}$ & $\begin{array}{l}100-1000 \mathrm{~nm} \\
7800\end{array}$ & $\begin{array}{l}\text { Total } \\
32800\end{array}$ & \\
\hline $\begin{array}{l}\text { Lanzhou, } \\
\text { urban }\end{array}$ & $\begin{array}{l}2012.09- \\
2013.08\end{array}$ & $\begin{array}{l}10-25 \mathrm{~nm} \\
1800\end{array}$ & $\begin{array}{l}25-100 \mathrm{~nm} \\
16100\end{array}$ & $\begin{array}{l}100-1000 \mathrm{~nm} \\
5000\end{array}$ & $\begin{array}{l}\text { Total } \\
22800\end{array}$ & $\begin{array}{l}\text { Zhao et al. } \\
(2015 b)\end{array}$ \\
\hline $\begin{array}{l}\text { Nanjing, } \\
\text { sub-urban }\end{array}$ & $\begin{array}{l}2011.12- \\
2013.11\end{array}$ & $\begin{array}{l}6-30 \mathrm{~nm} \\
5300\end{array}$ & $\begin{array}{l}30-100 \mathrm{~nm} \\
8000\end{array}$ & $\begin{array}{l}100-800 \mathrm{~nm} \\
5800\end{array}$ & $\begin{array}{l}\text { Total } \\
19200\end{array}$ & Qi et al. (2015) \\
\hline $\begin{array}{l}\text { Shandianzi, } \\
\text { rural }\end{array}$ & $\begin{array}{l}2008.03- \\
2009.08\end{array}$ & $\begin{array}{l}3-25 \mathrm{~nm} \\
3600\end{array}$ & $\begin{array}{l}25-100 \mathrm{~nm} \\
4400\end{array}$ & $\begin{array}{l}100-1000 \mathrm{~nm} \\
3500\end{array}$ & $\begin{array}{l}\text { Total } \\
11500\end{array}$ & $\begin{array}{l}\text { Shen et al. } \\
(2011)\end{array}$ \\
\hline $\begin{array}{l}\text { Waliguan, } \\
\text { rural, mountain }\end{array}$ & $\begin{array}{l}2005.08^{-} \\
2007.05\end{array}$ & $\begin{array}{l}12-21 \mathrm{~nm} \\
570\end{array}$ & $\begin{array}{l}21-95 \mathrm{~nm} \\
1100\end{array}$ & $\begin{array}{l}95-570 \mathrm{~nm} \\
430\end{array}$ & $\begin{array}{l}\text { Total } \\
2000\end{array}$ & $\begin{array}{l}\text { Kivekäs et al. } \\
\text { (2009) }\end{array}$ \\
\hline $\begin{array}{l}\text { Mt. Tai } \\
\text { rural, mountain }\end{array}$ & $\begin{array}{l}2010.07- \\
2012.02 \\
\end{array}$ & $\begin{array}{l}3-25 \mathrm{~nm} \\
3200\end{array}$ & $\begin{array}{l}25-100 \mathrm{~nm} \\
5200\end{array}$ & $\begin{array}{l}100-1000 \mathrm{~nm} \\
3400\end{array}$ & $\begin{array}{l}\text { Total } \\
11800\end{array}$ & $\begin{array}{l}\text { Shen et al. } \\
(2016 b)\end{array}$ \\
\hline
\end{tabular}


Table 2 Concentrations of SEOCs in China

\begin{tabular}{|c|c|c|c|c|c|c|c|c|c|c|c|c|c|c|c|c|}
\hline & \multirow[b]{2}{*}{ Site-description } & \multirow[b]{2}{*}{ Study period } & \multicolumn{7}{|c|}{ Concentration $\left(\mu \mathrm{g} \mathrm{m}^{-3}\right)$} & \multicolumn{6}{|c|}{ Concentration $\left(\mathrm{ng} \mathrm{m}^{-3}\right)$} & \multirow[b]{2}{*}{ Reference } \\
\hline & & & $\mathrm{PM}_{2.5}$ & OC & WSOC & alkanes & $\begin{array}{l}\text { fatty } \\
\text { acid }\end{array}$ & sugars & phthalates & $\begin{array}{l}\text { fatty } \\
\text { alcohols }\end{array}$ & $\begin{array}{c}\text { polyols } \\
\& \\
\text { polyacids } \\
\end{array}$ & $\begin{array}{l}\text { lignin \& } \\
\text { resin } \\
\text { products }\end{array}$ & sterols & PAHs & hopanes & \\
\hline Beijing & Urban & 2006.9-2007.8 & & & & 832 & 324 & & & & & & & 113 & & Li et al. (2013) \\
\hline Beijing & Capital of China & $2003.1,2003.6-7$ & 89 & 17.5 & & 268 & 443 & 122 & 290 & 15 & 60 & 10.1 & 46.3 & 108 & 11.2 & $\begin{array}{l}\text { Wang et al. } \\
\text { (2006a) }\end{array}$ \\
\hline Beijing & Urban & $2002.7,2002.11$ & & 23.5 & 6.32 & 322 & 664 & & & & & & & 122 & & $\begin{array}{l}\text { Feng) et al. } \\
\text { al. (2006b) }\end{array}$ \\
\hline Beijing & Urban & 2001.8-2001.7 & & & & 163 & 385 & & & & 26.5 & & & 66.2 & 6.9 & $\begin{array}{l}\text { Huang et al. } \\
\text { (2006) }\end{array}$ \\
\hline Changchun & $\begin{array}{c}\text { continental \& } \\
\text { industrial }\end{array}$ & $2003.1,2003.6-7$ & 97 & 25.5 & & 353 & 598 & 309 & 264 & 29.5 & 132 & 24.5 & 114 & 111 & 12.4 & $\begin{array}{l}\text { Wang et al. } \\
\text { (2006a) }\end{array}$ \\
\hline $\begin{array}{l}\text { Changdao } \\
\text { island }\end{array}$ & & 2003.3-2004.1 & & 8.35 & 4.08 & 96.2 & 174 & 66 & & & & & & 45.1 & 11.3 & Feng et al. (2007) \\
\hline Chongqing & $\begin{array}{c}\text { continental \& } \\
\text { industrial }\end{array}$ & $2003.1,2003.6-7$ & 277 & 67 & & 638 & 2041 & 1767 & 1268 & 240 & 302 & 99 & 399 & 361 & 22 & $\begin{array}{l}\text { Wang et al. } \\
\text { (2006a) }\end{array}$ \\
\hline Guangzhou & $\begin{array}{l}\text { industrial \& } \\
\text { commercial }\end{array}$ & $2003.1,2003.6-7$ & 156 & 47 & & 575 & 1859 & 514 & 382 & 46.6 & 133 & 100 & 464 & 167 & 30.9 & $\begin{array}{l}\text { Wang et al. } \\
\text { (2006a) }\end{array}$ \\
\hline Guangzhou & Urban & $2002.12,2003.7$ & & 20.5 & 6.7 & 121 & 740 & & & & & & & 61.8 & & $\begin{array}{l}\text { Feng et al. } \\
\text { (2006b) }\end{array}$ \\
\hline Hangzhou & continental & $2003.1,2003.6-7$ & 111 & 20 & & 250 & 606 & 171 & 390 & 16 & 85 & 14.2 & 78.5 & 26.8 & 4.13 & $\begin{array}{l}\text { Wang et al. } \\
\text { (2006a) }\end{array}$ \\
\hline HongKong & $\begin{array}{c}\text { coastal \& } \\
\text { commercial }\end{array}$ & $2003.1,2003.6-7$ & 63 & 13 & & 103 & 274 & 78.7 & 288 & 17 & 73 & 3.3 & 17.8 & 7.85 & 2.36 & $\begin{array}{l}\text { Wang et al. } \\
\text { (2006a) }\end{array}$ \\
\hline HongKong & Urban & 2000.11-2001.11 & & 8.45 & & 57.9 & 175 & & & & & & & 8.05 & & Sin et al. (2005) \\
\hline Jinchang & $\begin{array}{l}\text { Asian dust source } \\
\text { regions }\end{array}$ & $2003.1,2003.6-7$ & 124 & 15.5 & & 291 & 370 & 106 & 188 & 31.5 & 74 & 8.65 & 39.6 & 109 & 3.75 & $\begin{array}{l}\text { Wang et al. } \\
(2006 a)\end{array}$ \\
\hline Lin'an & Background & 2008.4-2009-1 & 59.7 & 10.3 & 5.31 & 60 & 135 & 136 & & & & & & 25 & 2.9 & $\begin{array}{l}\text { Feng et al. } \\
\text { (2015a) }\end{array}$ \\
\hline Mt. Tai & & 2006.6 & & 14.5 & 9.2 & 117 & 204 & 409 & 255 & 129 & 97 & 6.05 & 13.5 & 12.5 & 1.4 & Fu et al. (2012) \\
\hline Qingdao & coastal & $2003.1,2003.6-7$ & 65.5 & 11 & & 168 & 361 & 89 & 134 & 11 & 64 & 28 & 18.5 & 45.6 & 3.57 & $\begin{array}{l}\text { Wang et al. } \\
\text { (2006a) }\end{array}$ \\
\hline Qingdao & & 2001.6-2002.5 & & & & 217 & 654 & & & & & & & 87.5 & & Guo et al. (2003) \\
\hline Shanghai & Urban & 2009.1.21-2.6 & 91 & 11 & & 104 & 210 & & & & & & & 36.6 & 6.7 & $\begin{array}{l}\text { Feng et al. } \\
\text { (2012a) }\end{array}$ \\
\hline Shanghai & $\begin{array}{l}\text { industrial \& } \\
\text { commercial }\end{array}$ & $2003.1,2003.6-7$ & 81 & 15.5 & & 194 & 463 & 258 & 477 & 26 & 107 & 17.3 & 48 & 46 & 9.1 & $\begin{array}{l}\text { Wang et al. } \\
\text { (2006a) }\end{array}$ \\
\hline Shanghai & Urban & $2002.11,2003.8$ & & 10.3 & 4.07 & 83 & 255 & & & & & & & 30 & & $\begin{array}{l}\text { (2006a); Feng et } \\
\text { al. (2006b) }\end{array}$ \\
\hline
\end{tabular}




\begin{tabular}{|c|c|c|c|c|c|c|c|c|c|c|c|c|c|c|c|c|}
\hline & \multirow[b]{2}{*}{ Site-description } & \multirow[b]{2}{*}{ Study period } & \multicolumn{3}{|c|}{ concentration $\left(\mu \mathrm{g} \mathrm{m}^{-3}\right)$} & \multicolumn{10}{|c|}{ concentration $\left(\mathrm{ng} \mathrm{m}^{-3}\right)$} & \multirow[b]{2}{*}{ Reference } \\
\hline & & & $\mathrm{PM}_{2.5}$ & $\mathrm{OC}$ & WSOC & alkanes & $\begin{array}{l}\text { fatty } \\
\text { acid }\end{array}$ & sugars & phthalates & $\begin{array}{c}\text { fatty } \\
\text { alcohols }\end{array}$ & $\begin{array}{c}\text { polyols } \\
\& \\
\text { polyacids }\end{array}$ & $\begin{array}{l}\text { lignin \& } \\
\text { resin } \\
\text { products }\end{array}$ & sterols & PAHs & hopanes & \\
\hline Shenzhen & Urban & 2009.1-2009.12 & & & & 56 & 253 & & & & 25.2 & & & 148 & 2.51 & $\begin{array}{l}\text { Huang et al. } \\
\text { (2012b) }\end{array}$ \\
\hline Taizhou & e-waste & 2006.6, 2007.1 & 87.5 & 33.1 & & 232 & 332 & 179 & 212 & & & & & 103 & 11.2 & Gu et al. (2010) \\
\hline Tianjin & industrial & $2003.1,2003.6-7$ & 101 & 19 & & 225 & 673 & 165 & 541 & 17.1 & 101 & 9.25 & 43 & 77 & 8.4 & $\begin{array}{c}\text { Wang et al. } \\
\text { (2006a) }\end{array}$ \\
\hline Wuhan & $\begin{array}{l}\text { industrial \& } \\
\text { commercial }\end{array}$ & $2003.1,2003.6-7$ & 86 & 21 & & 219 & 628 & 340 & 303 & 17 & 121 & 23.7 & 56 & 60.4 & 1.8 & $\begin{array}{l}\text { Wang et al. } \\
\text { (2006a) }\end{array}$ \\
\hline Xi'an & $\begin{array}{l}\text { continental \& } \\
\text { industrial }\end{array}$ & $2003.1,2003.6-7$ & 215 & 60 & & 865 & 1663 & 1711 & 554 & 286 & 250 & 174 & 736 & 403 & 31.9 & $\begin{array}{c}\text { Wang et al. } \\
\text { (2006a) }\end{array}$ \\
\hline Xiamen & $\begin{array}{c}\text { coastal \& } \\
\text { commercial }\end{array}$ & $2003.1,2003.6-7$ & 47.5 & 12.2 & & 242 & 300 & 79.5 & 175 & 9.85 & 83 & 6.75 & 10.5 & 14.3 & 1.7 & $\begin{array}{l}\text { Wang et al. } \\
\text { (2006a) }\end{array}$ \\
\hline Yulin & $\begin{array}{c}\text { continental, close to } \\
\text { a desert }\end{array}$ & $2003.1,2003.6-7$ & 85.5 & 20 & & 372 & 487 & 52 & 162 & 23.2 & 89 & 5.6 & 283 & 103 & 11 & $\begin{array}{c}\text { Wang et al. } \\
\text { (2006a) }\end{array}$ \\
\hline
\end{tabular}


Table 3 Summary of modeling studies evaluating the effect of recent and future control measures on $\mathrm{PM}_{2.5}$ concentrations in China

\begin{tabular}{|c|c|c|c|c|c|}
\hline Source & Period & Region & Model & Scenarios & Major results \\
\hline \multicolumn{6}{|c|}{ Effect of recent control measures on $\mathbf{P M}_{2.5}$ concentrations } \\
\hline $\begin{array}{l}\text { Wang et al. } \\
(2010)\end{array}$ & $\begin{array}{l}\text { 2005-2010: } \\
\text { projection }\end{array}$ & China & MM5/CMAQ & $\begin{array}{l}\text { A } 2010 \text { BAU scenario, a } 2010 \mathrm{SO}_{2} \text { control } \\
\text { scenario based on the } 11^{\text {th }} \text { Five-Year Plan, and a } \\
2010 \text { NOx control scenario }\end{array}$ & $\begin{array}{l}\text { Under the } 2010 \mathrm{SO}_{2} \text { control scenario, annual concentrations of } \mathrm{SO}_{4}{ }^{2-} \text { and } \mathrm{PM}_{2.5} \text { in Eastern China were estimated } \\
\text { to decline by } 2-16 \mu \mathrm{g} \mathrm{m}^{-3}(12-40 \%) \text { and } 3-15 \mu \mathrm{g} \mathrm{m}^{-3}(4-25 \%) \text {, respectively, compared with the } 2010 \mathrm{BAU} \\
\text { scenario. Under the } 2010 \mathrm{NOx} \text { control scenario, } \mathrm{NO}_{3}{ }^{-} \text {and } \mathrm{PM}_{2.5} \text { concentrations decline by } 2-7 \mu \mathrm{g} \mathrm{m}^{-3}(20-40 \%) \\
\text { and 2-14 } \mu \mathrm{g} \mathrm{m}^{-3}(3-12 \%) \text {, respectively. }\end{array}$ \\
\hline $\begin{array}{l}\text { Wang et al. } \\
(2014 \mathrm{a})\end{array}$ & $\begin{array}{l}\text { 2005-2010: post- } \\
\text { evaluation } \\
\text { 2010-2015: } \\
\text { projection }\end{array}$ & China & WRF/CMAQ & $\begin{array}{l}\text { A } 2010 \text { BAU scenario, a } 2010 \text { scenario assuming } \\
\mathrm{SO}_{2} \text { control in the } 11^{\text {th }} \text { Five-Year Plan, a } 2015 \\
\text { BAU scenario, and a } 2015 \text { scenario assuming } \mathrm{NO}_{\mathrm{X}} \\
\text { control in the } 12^{\text {th }} \text { Five-Year Plan }\end{array}$ & $\begin{array}{l}\text { The } \mathrm{SO}_{2} \text { control in the } 11^{\text {th }} \text { Five-Year Plan decreased ambient } \mathrm{SO}_{4}{ }^{2-} \text { concentrations by } 8 \%-10 \% \text { from the } 2005 \\
\text { level in Eastern China. } \mathrm{NO}_{\mathrm{X}} \text { control measures assumed in the } 12^{\text {th }} \text { Five-Year Plan would reduce the } \mathrm{NO}_{3}{ }^{-} \\
\text {concentration in Eastern China by 3-14\% from } 2010 \text { to } 2015 \text {. }\end{array}$ \\
\hline $\begin{array}{l}\text { Zhao et al. } \\
\text { (2013a) }\end{array}$ & $\begin{array}{l}\text { 2005-2010: post- } \\
\text { evaluation }\end{array}$ & China & WRF/CMAQ & $\begin{array}{l}\text { A } 2005 \text { scenario, a } 2010 \text { scenario, and a } 2005 \\
\text { scenario using the meteorology data of } 2010\end{array}$ & $\begin{array}{l}\text { As an effect solely of emission changes from } 2005 \text { to } 2010, \mathrm{PM}_{2.5} \text { concentrations decreased by } 2-17 \mu \mathrm{g} \mathrm{m}^{-3} \text { in } \\
\text { most of the North China Plain, the YRD region and the PRD region, while increasing by } 4.5-16 \mu \mathrm{g} \mathrm{m}^{-3} \text { in most } \\
\text { of the Sichuan Basin and Hubei Province. }\end{array}$ \\
\hline $\begin{array}{l}\text { Zhao et al. } \\
\text { (2013d) }\end{array}$ & $\begin{array}{l}\text { 2010-2015: } \\
\text { projection }\end{array}$ & China & WRF/CMAQ & $\begin{array}{l}\text { A } 2015 \text { BAU scenario, a } 2015 \mathrm{NO}_{\mathrm{X}} \text { control } \\
\text { scenario, and a } 2015 \text { joint } \mathrm{SO}_{2} / \mathrm{NO}_{\mathrm{X}} \text { control } \\
\text { scenario, both based on } 12^{\text {th }} \text { Five-Year Plan }\end{array}$ & $\begin{array}{l}\text { Under the } 2015 \mathrm{NOx} \text { control scenario, the annual } \mathrm{PM}_{2.5} \text { concentration was expected to decline by } 1.5-6 \mu \mathrm{g} \mathrm{m}^{-3} \\
(1.6-8.5 \%) \text { in most of Eastern China, compared with the } 2015 \mathrm{BAU} \text { scenario. The corresponding } \mathrm{PM}_{2.5} \\
\text { reduction could be } 3-8.3 \mu \mathrm{g} \mathrm{m}^{-3}(3.2-13 \%) \text { under the joint } \mathrm{SO}_{2} / \mathrm{NO}_{\mathrm{x}} \text { controls. }\end{array}$ \\
\hline $\begin{array}{l}\text { Chinese } \\
\text { Academy of } \\
\text { Engineering } \\
\text { (2016) }\end{array}$ & $\begin{array}{l}\text { 2013-2015: post- } \\
\text { evaluation }\end{array}$ & China & WRF/CMAQ & $\begin{array}{l}\text { A } 2013 \text { scenario and a } 2015 \text { scenario with the } \\
\text { effect of "Action Plan" considered }\end{array}$ & $\begin{array}{l}\text { The implementation of "Action Plan" decreased } \mathrm{SO}_{2}, \mathrm{NO}_{\mathrm{x}} \text {, and } \mathrm{PM}_{2.5} \text { emissions by } 29 \%, 19 \% \text {, and } 22 \% \text { during } \\
\text { 2013-2015, accounting for about } 24 \% \text { reduction in average } \mathrm{PM}_{2.5} \text { concentrations in } 74 \text { key cities. } \\
\text { Meteorological variability played a negligible role in the changes of } \mathrm{PM}_{2.5} \text { concentrations from } 2013 \text { to } 2015 \text {. }\end{array}$ \\
\hline \multicolumn{6}{|c|}{$\begin{array}{l}\text { Effect of future control measures on } \mathrm{PM}_{2.5} \text { concentrations } \\
\end{array}$} \\
\hline $\begin{array}{lll}\text { Xing } & \text { et } & \text { al. } \\
(2011) & \end{array}$ & $2005-2020$ & $\begin{array}{l}\text { Eastern } \\
\text { China }\end{array}$ & MM5/CMAQ & $\begin{array}{l}\text { Four } 2020 \text { scenarios assuming different } \\
\text { combinations of energy paths and emission control } \\
\text { strategies }\end{array}$ & $\begin{array}{l}\text { The reference scenario was projected to increase average } \mathrm{PM}_{2.5} \text { concentrations in Eastern China by } 8 \% \text { from } \\
\text { the } 2005 \text { level and the most stringent scenario was estimated to reduce average } \mathrm{PM}_{2.5} \text { concentration by } 16 \% \\
\text { from the } 2005 \text { level. }\end{array}$ \\
\hline $\begin{array}{ll}\text { Cai et al. } \\
(2016)\end{array}$ & $2012-2017$ & $\begin{array}{l}\text { JJJ } \\
\text { region }\end{array}$ & WRF/CMAQ & $\begin{array}{l}\text { A } 2017 \text { scenario assuming the enforcement of } \\
\text { "Action Plan" and a } 2020 \text { scenario assuming } \\
\text { extrapolation of "Action Plan" }\end{array}$ & $\begin{array}{l}\text { With the implementation of the "Action Plan", the ambient annual } \mathrm{PM}_{2.5} \text { concentrations in the JJJ region in } \\
2017 \text { and } 2020 \text { were projected to be } 28 \% \text { and } 38 \% \text { lower than those in } 2012 \text {, respectively. }\end{array}$ \\
\hline $\begin{array}{l}\text { Jiang et al. } \\
(2015 \mathrm{~b})\end{array}$ & $2012-2017$ & $\begin{array}{l}\text { PRD } \\
\text { region }\end{array}$ & WRF/CMAQ & $\begin{array}{l}\text { A } 2017 \text { scenario assuming the enforcement of } \\
\text { "Action Plan" }\end{array}$ & $\begin{array}{l}\text { The implementation of the "Action Plan" was estimated to lower the } \mathrm{PM}_{2.5} \text { concentration in the PRD region by } \\
17 \% \text { from the } 2012 \text { level. }\end{array}$ \\
\hline $\begin{array}{l}\text { Amann et al. } \\
(2008)\end{array}$ & $2005-2030$ & China & $\begin{array}{l}\text { source-receptor } \\
\text { relationship }\end{array}$ & $\begin{array}{l}\text { A } 2030 \text { baseline scenario and a } 2030 \text { control } \\
\text { scenario assuming uniform application of } \\
\text { advanced emission control technologies }\end{array}$ & $\begin{array}{l}\text { The } \mathrm{PM}_{2.5} \text { concentration would roughly remain the } 2005 \text { level under the } 2030 \text { baseline scenario. In the control } \\
\text { scenario, population-weighted } \mathrm{PM}_{2.5} \text { concentrations would decline by } 44 \% \text { from about } 80 \mu \mathrm{g} / \mathrm{m}^{3} \text { in } 2005 \text { to } 45 \\
\mu \mathrm{g} / \mathrm{m}^{3} \text { in } 2030 \text {. }\end{array}$ \\
\hline $\begin{array}{l}\text { Madaniyazi et } \\
\text { al. (2015) }\end{array}$ & $2005-2030$ & $\begin{array}{l}\text { Eastern } \\
\text { China }\end{array}$ & $\begin{array}{l}\text { MIROC-ESM- } \\
\text { CHEM }\end{array}$ & $\begin{array}{l}\text { A } 2030 \text { "current legislation" scenario (CLE) and a } \\
2030 \text { "maximum technically feasible reduction" } \\
\text { scenario (MFR) }\end{array}$ & $\begin{array}{l}\mathrm{PM}_{2.5} \text { concentration in Eastern China would decrease by } 0.62 \mu \mathrm{g} / \mathrm{m}^{3} \text { under the CLE scenario and } 20.41 \mu \mathrm{g} / \mathrm{m}^{3} \\
\text { under the MFR scenario by } 2030 \text { from the } 2005 \text { level. }\end{array}$ \\
\hline $\begin{array}{l}\text { GBD MAPS } \\
\text { Working } \\
\text { Group (2016) }\end{array}$ & $2013-2030$ & China & GEOS-Chem & $\begin{array}{l}\text { Four } 2030 \text { scenarios assuming different } \\
\text { combinations of energy paths and emission control } \\
\text { strategies }\end{array}$ & $\begin{array}{l}\mathrm{PM}_{2.5} \text { concentrations would decrease by } 2.0-5.1 \mu \mathrm{g} / \mathrm{m}^{3}(5-8 \%) \text { and } 14.6-40.3 \mu \mathrm{g} / \mathrm{m}^{3}(40-52 \%) \text { over four major } \\
\text { metropolitan regions in China from } 2013 \text { to } 2030 \text { under the BAU[1] scenario assuming current energy policies } \\
\text { and progressively strengthened emission control strategies, and the PC[2] scenario assuming very stringent } \\
\text { energy policies and emission control strategies, respectively. }\end{array}$ \\
\hline $\begin{array}{l}\text { Wang et al. } \\
(2015 \mathrm{~b})\end{array}$ & $2012-2030$ & China & CMAQ/RSM & $\begin{array}{l}\text { A } 2030 \text { scenario designed to meet the ambient } \\
\mathrm{PM}_{2.5} \text { standard of } 35 \mu \mathrm{g} / \mathrm{m}^{3}\end{array}$ & $\begin{array}{l}\text { National emissions of } \mathrm{SO}_{2}, \mathrm{NO}_{x}, \mathrm{PM}_{2.5} \text {, and NMVOC should be reduced by at least } 51 \%, 64 \%, 53 \% \text {, and } 36 \% \text {, } \\
\text { respectively, by } 2030 \text { from the } 2012 \text { levels, in order to meet the ambient } \mathrm{PM}_{2.5} \text { standard. }\end{array}$ \\
\hline
\end{tabular}




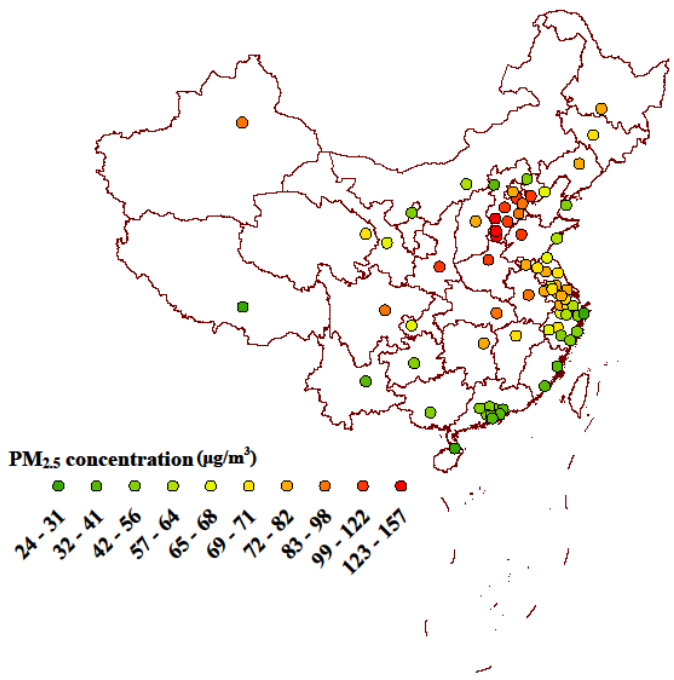

(a) 2013

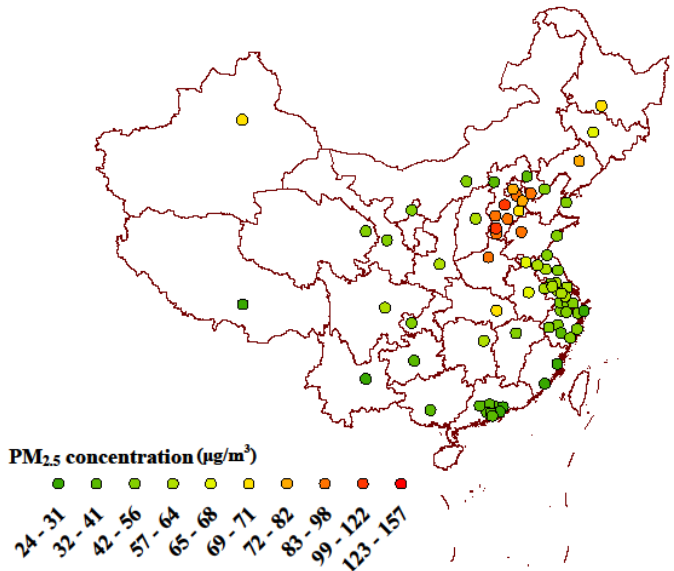

(c) 2015

(d) $2015-2013$

Figure 1 Annual average $\mathrm{PM}_{2.5}$ mass concentrations in China (a)_in 2013, (b) in 2014, (c) in 2015.

(d) Difference of $\mathrm{PM}_{2.5}$ concentration between 2015 and 2013.

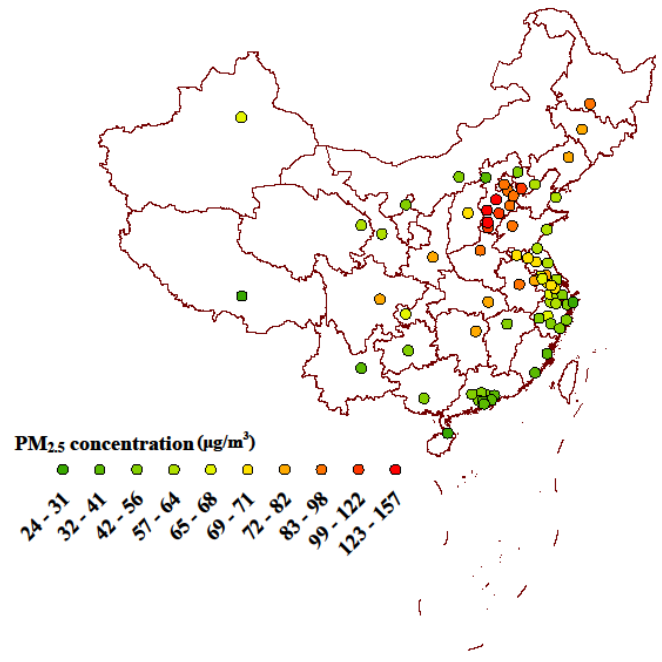

(b) 2014

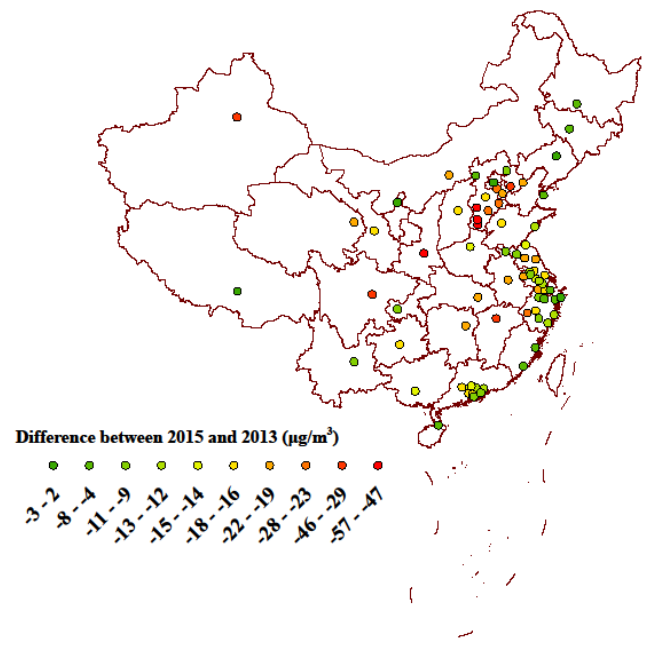

1226 


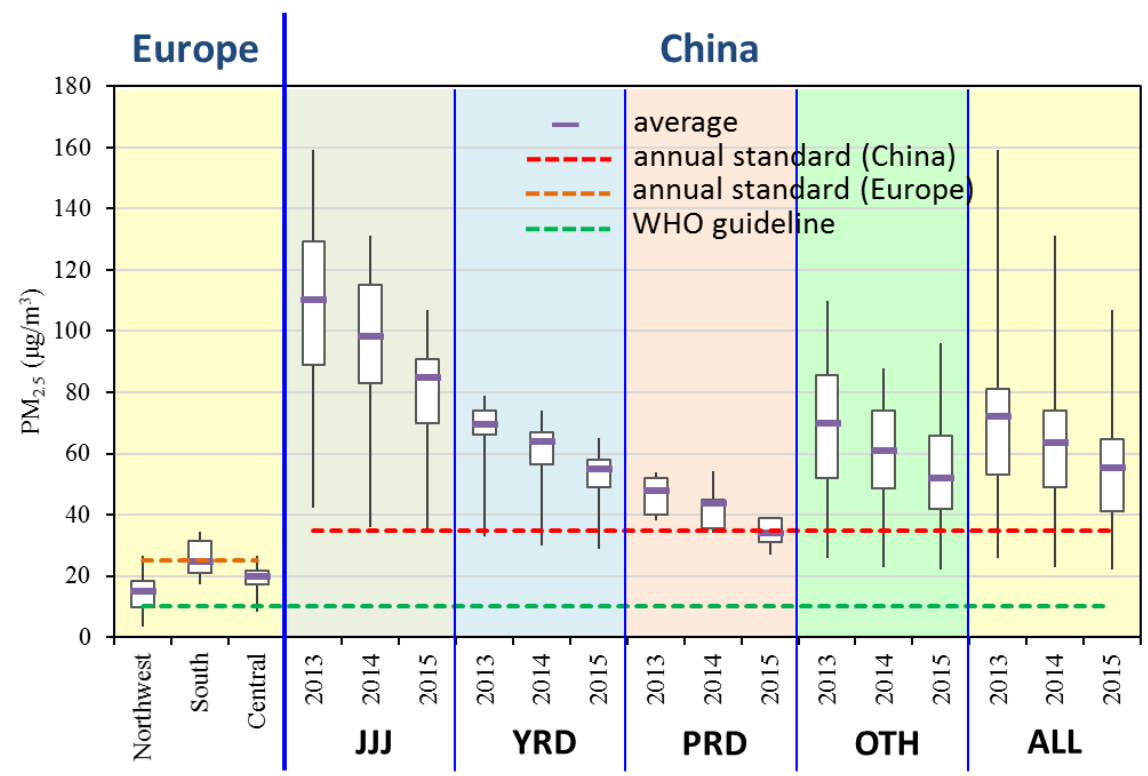

Figure 2 Annual average $\mathrm{PM}_{2.5}$ concentration in Europe and China. The grey line shows the average value of $\mathrm{PM}_{2.5}$ concentration of in large and middle-size cities. The whisker and box show the min ( $\max )$ value and $25(75) \%$ percentiles, respectively. The red, orange, and green dashed line shows the air quality standard of China and Europe, and the WHO guideline, respectively. 


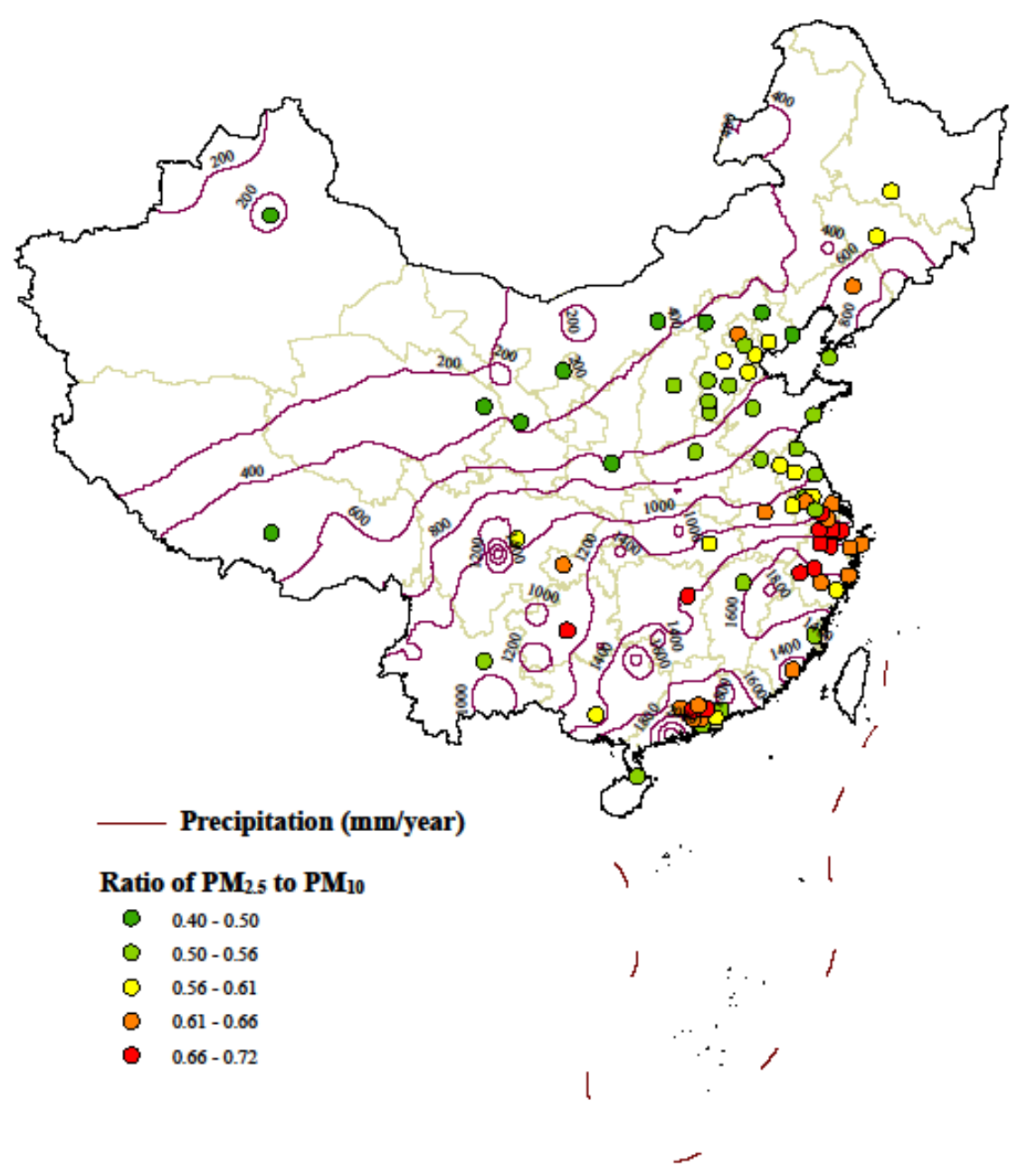

Figure 3 Ratio of $\mathrm{PM}_{2.5}$ to $\mathrm{PM}_{10}$ in China in 2015 and isohyetal line. 


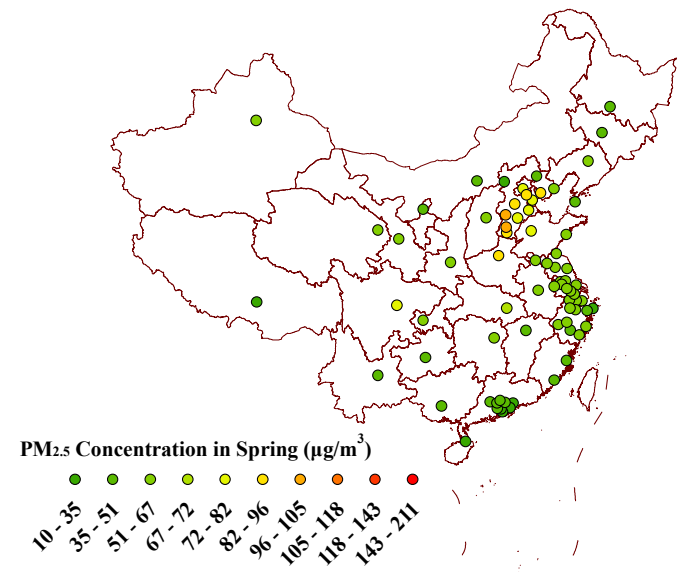

(a) Spring

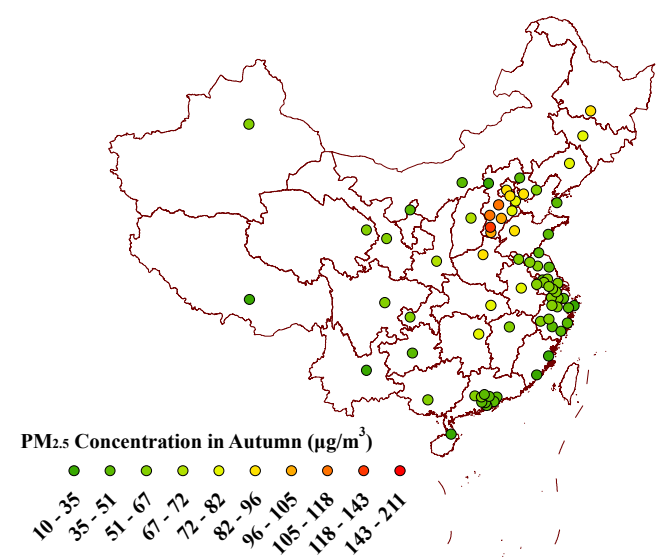

(c) Autumn

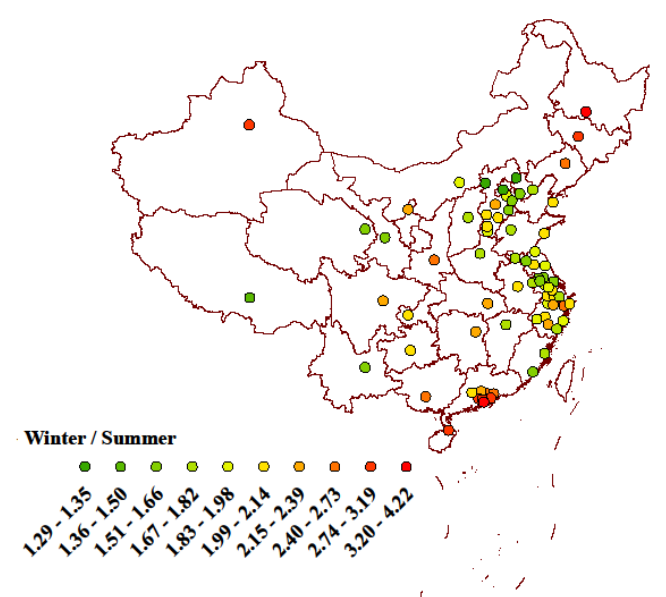

PM2.5 Concentration in Summer $\left(\mu \mathrm{g} / \mathrm{m}^{3}\right)$

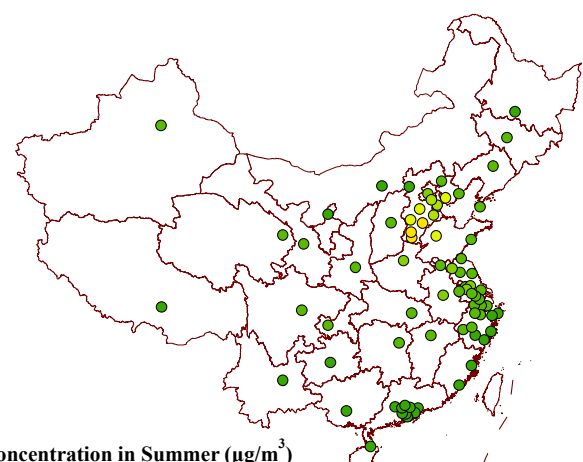

0

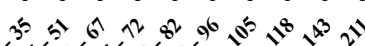

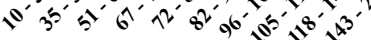

(b) Summer

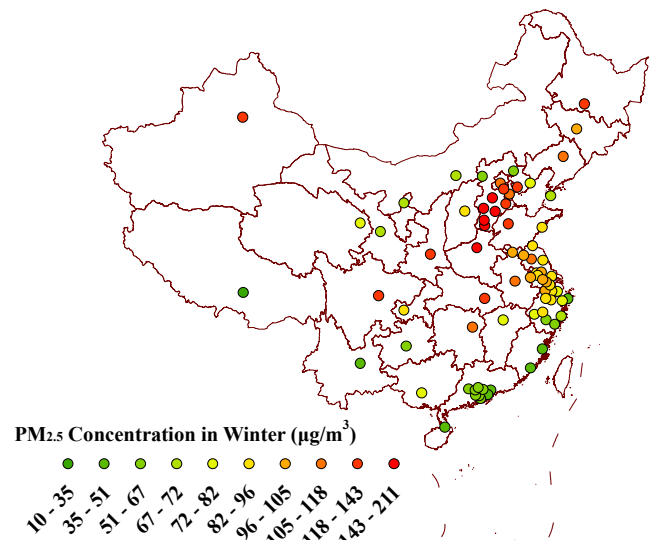

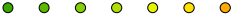

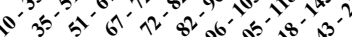

(d) Winter

(e) Winter / Summer

Figure 4 seasonal variation of $\mathrm{PM}_{2.5}$ mass concentration 


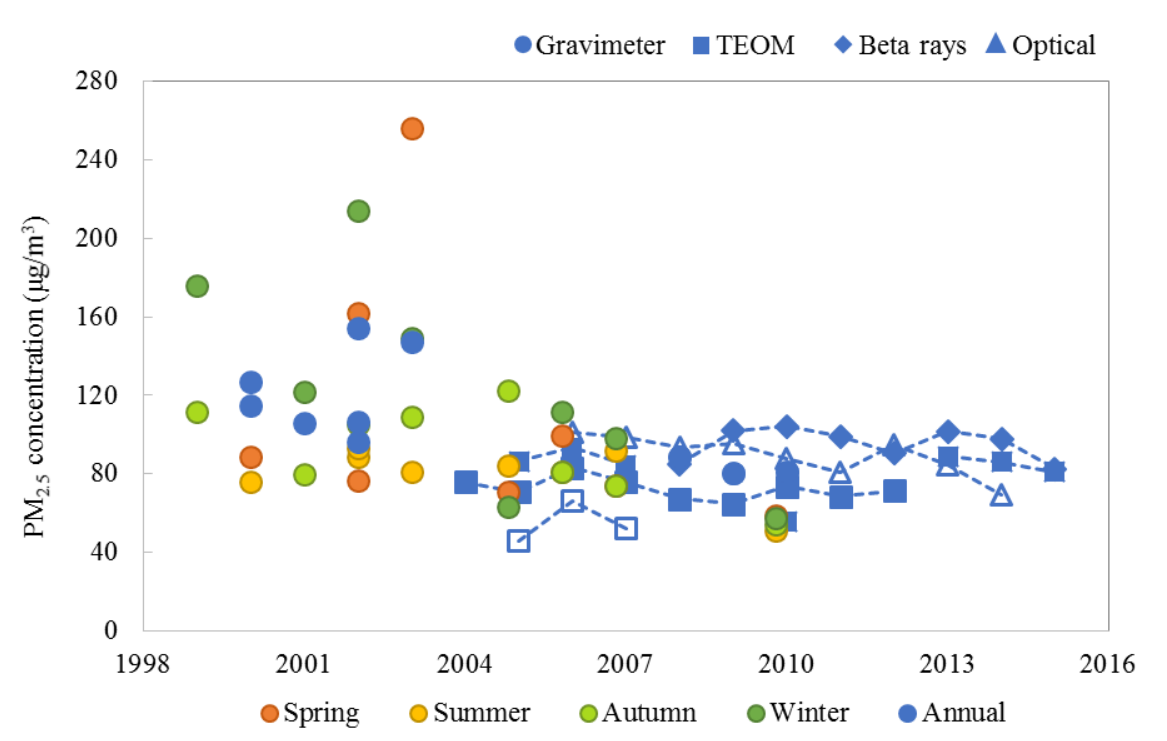

(a) Beijing

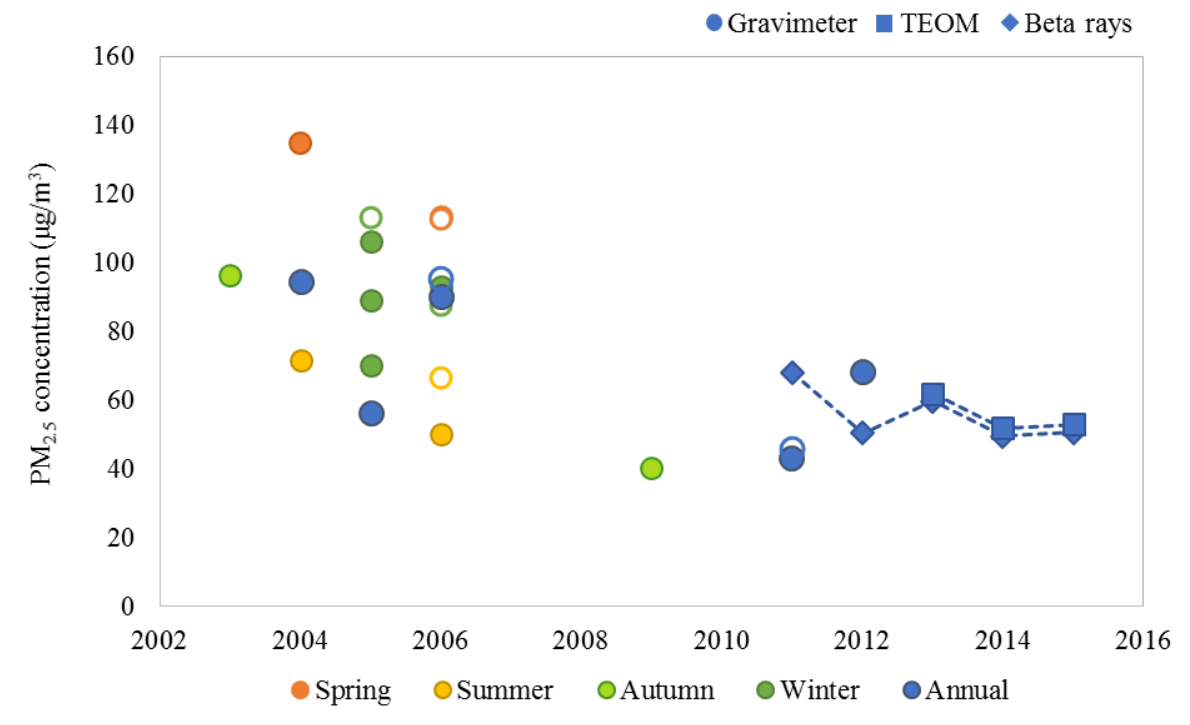

(b) Shanghai

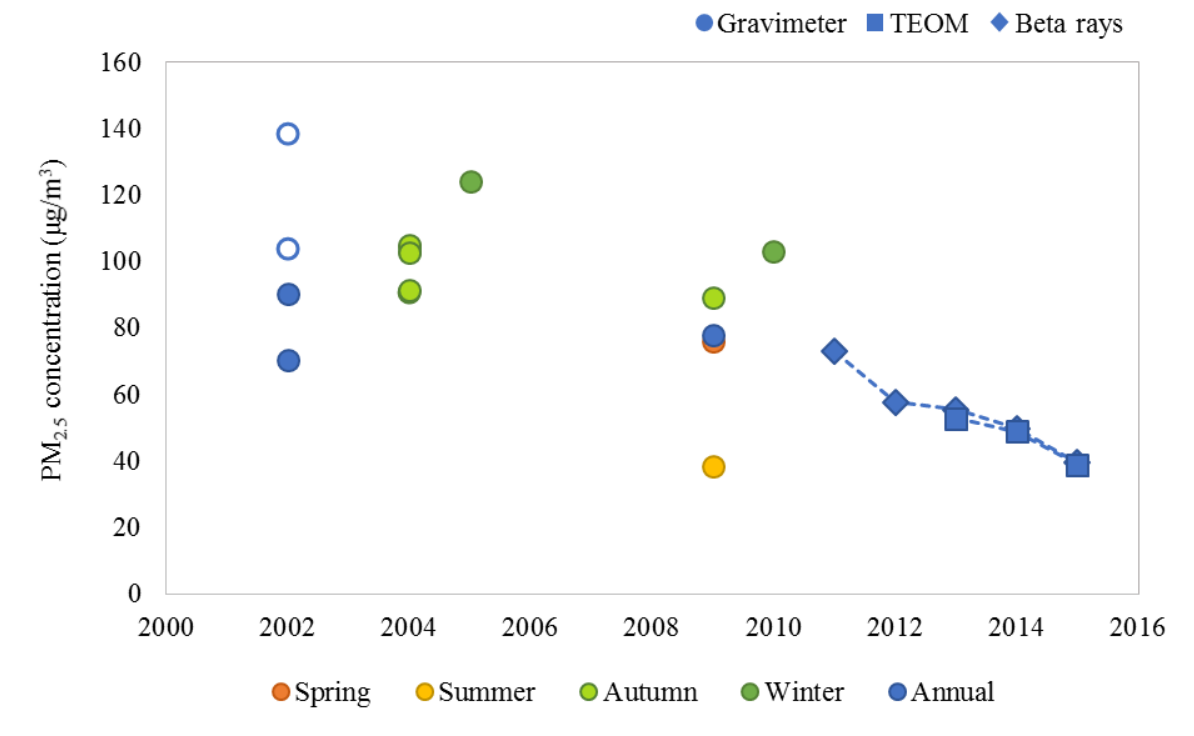


(c) Guangzhou

1238 Figure 5 Interannual trend of average $\mathrm{PM}_{2.5}$ mass concentrations in megacities. Symbols with dashed 1239 line shows multi-year studies. Blue represents annual average $\mathrm{PM}_{2.5}$ concentration. Orange, yellow, 1240 light green, and dark green represent average concentration of spring, summer, autumn, and winter, 1241 respectively. Circle, square, diamond, and triangle represent measurement methods, i.e., gravimeter, TEOM, beta rays, and optical method, respectively. Solid and hollow represent urban area and rural area, respectively. 


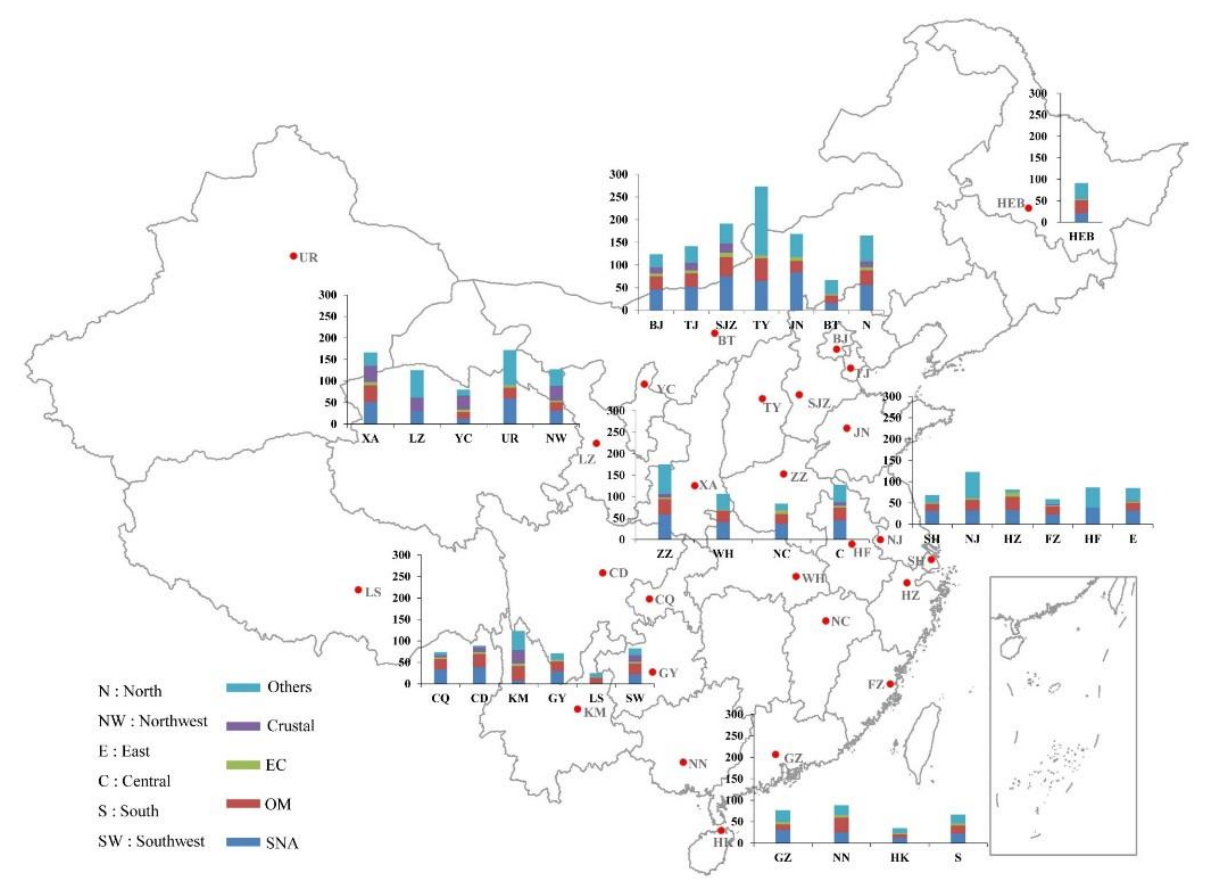

Figure 6 Annual average concentrations $\left(\mu \mathrm{g} \mathrm{m}^{-3}\right)$ of $\mathrm{PM}_{2.5}$ and its major chemical components in 27 1247 major cities (23 provincial capitals plus 4 municipalities) and different regions over China 


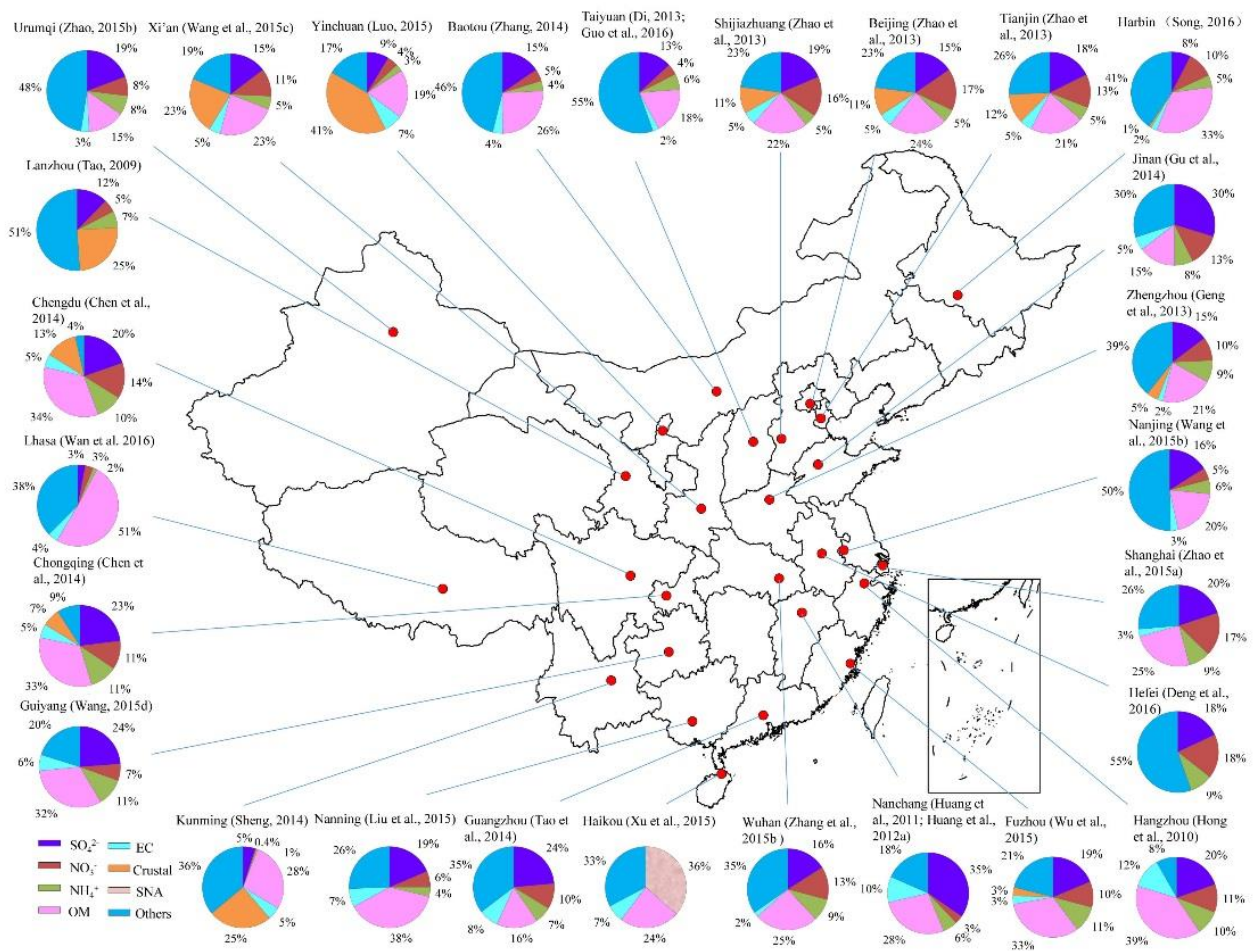

1250

Figure 7 Averaged $\mathrm{PM}_{2.5}$ speciation across China

1251 


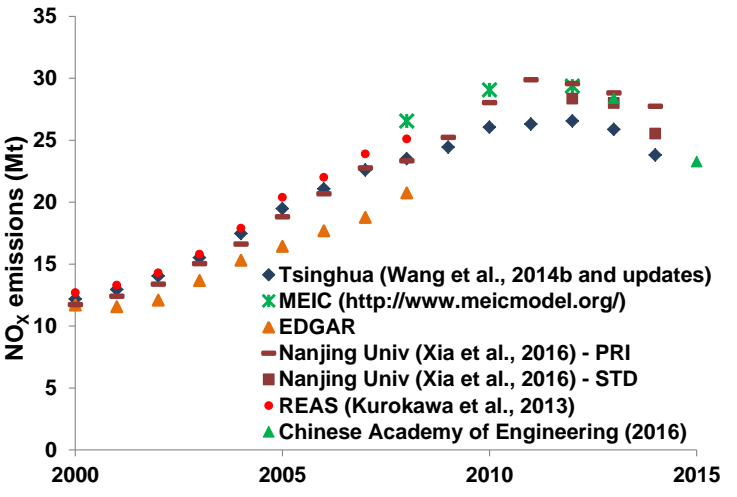

(a) $\mathrm{NO}_{\mathrm{X}}$

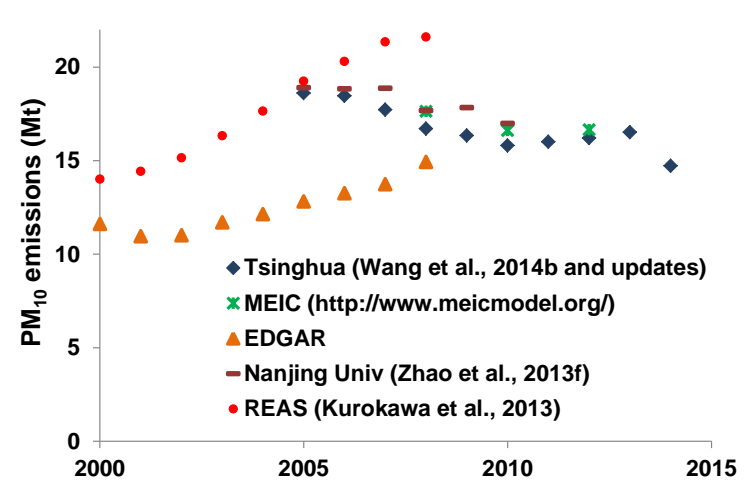

(c) $\mathrm{PM}_{10}$

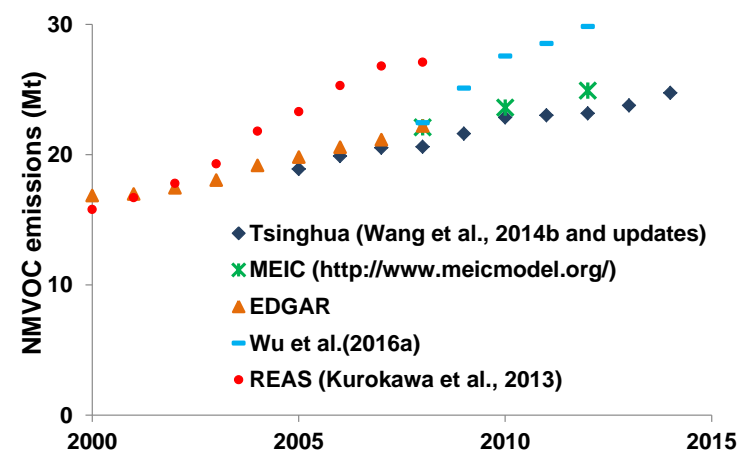

(e) NMVOC

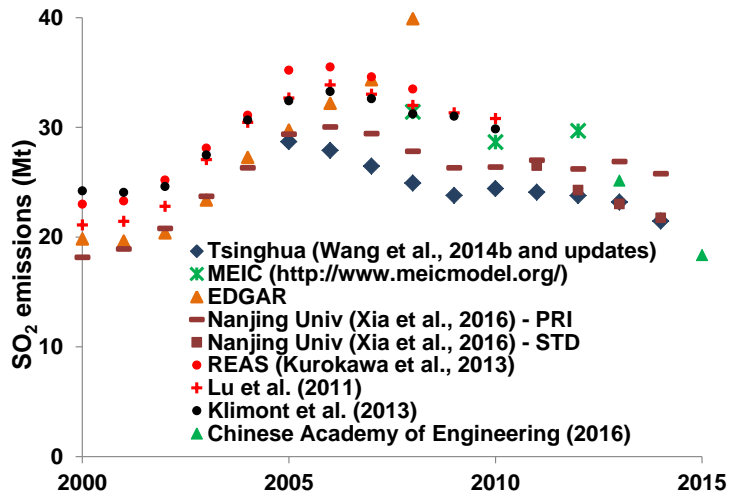

(b) $\mathrm{SO}_{2}$

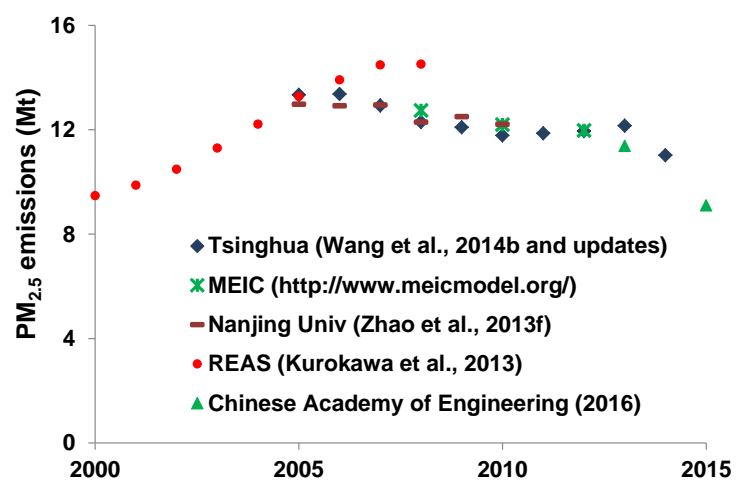

(d) $\mathrm{PM}_{2.5}$

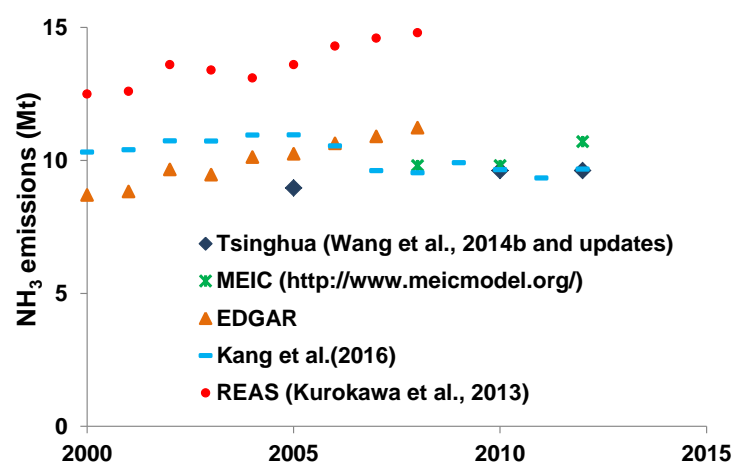

(f) $\mathrm{NH}_{3}$

1252 Figure 8 Emissions of major air pollutants in China during 2000-2015: (a) $\mathrm{NO}_{\mathrm{X}}$, (b) $\mathrm{SO}_{2}$, (c) $\mathrm{PM}_{10}$, (d) 


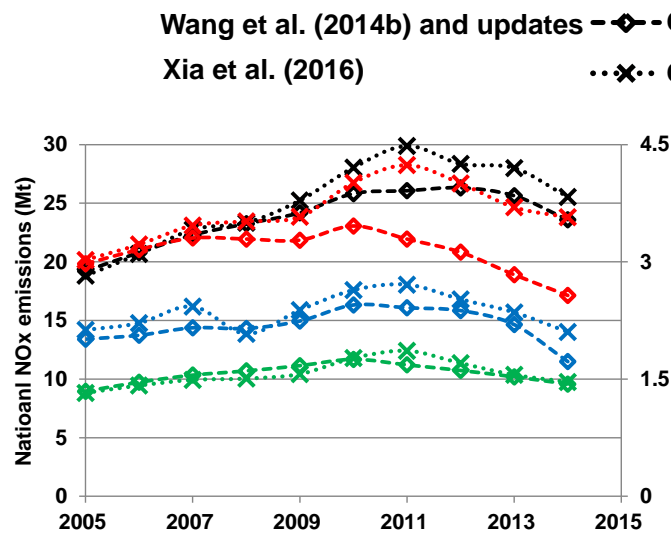

(a) $\mathrm{NO}_{\mathrm{X}}$

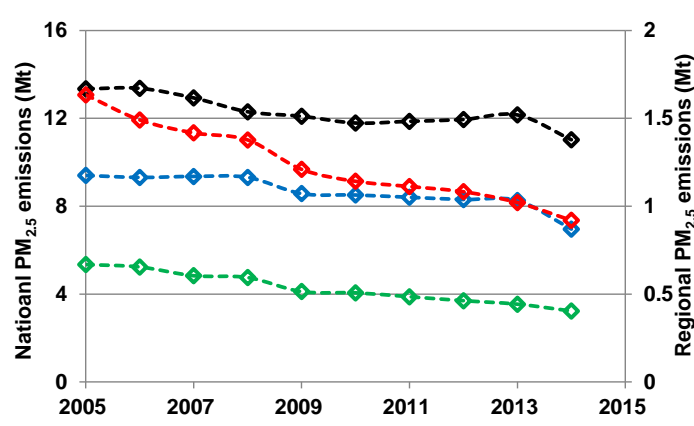

(c) $\mathrm{PM}_{2.5}$

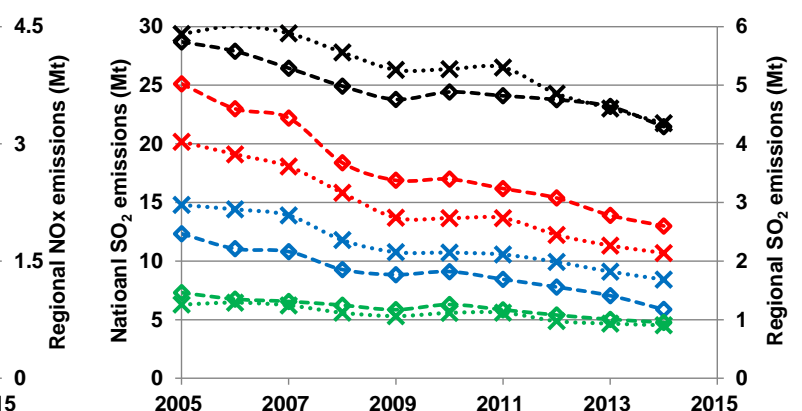

(b) $\mathrm{SO}_{2}$

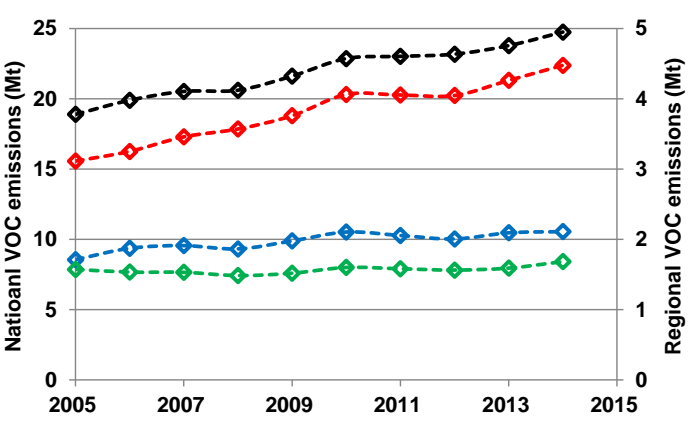

(d) NMVOC

1256 Figure 9 Emissions of major air pollutants in key metropolitan regions of China during 2005-2015: (a) $\mathrm{NO}_{\mathrm{X}}$, (b) $\mathrm{SO}_{2}$, (c) $\mathrm{PM}_{2.5}$, (d) NMVOC. The results are derived from Wang et al. (2014b) and subsequent updates, and the STD case of Xia et al. (2016). 
Tsinghua (Zhao et al., 2013c; Wang et al., 2014b) BAU[0] $\diamond \mathrm{BAU[1]} \diamond \mathrm{BAU}[2] \quad \square \mathrm{PC}[0] \quad \square \mathrm{PC}[1] \quad$ 回PC[2]

Tsinghua (Cai et al., 2016)

IIASA (Cofala et al., 2012)

Nanjing Univ (Zhao et al., 2014)

Wei et al. (2011)

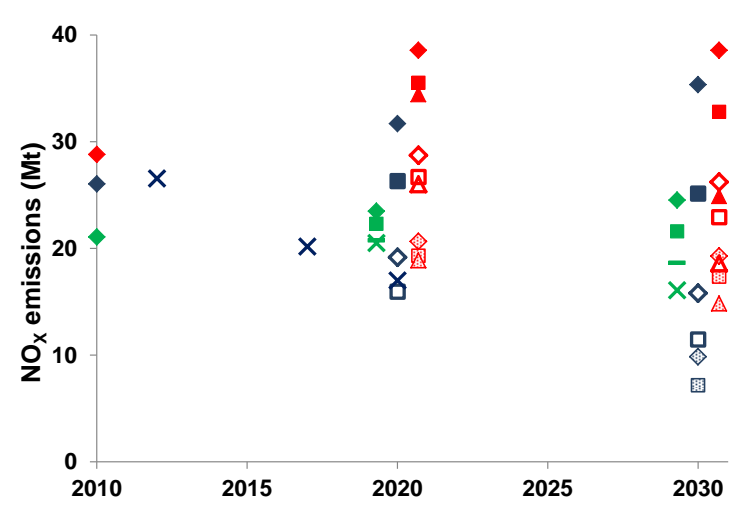

(a) $\mathrm{NO}_{\mathrm{X}}$

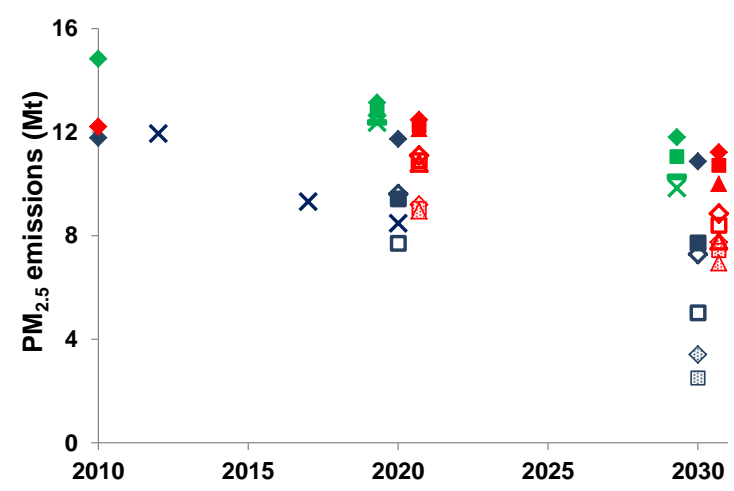

(c) $\mathrm{PM}_{2.5}$ $\times$ "National Ten"

$\checkmark$ current policy $n$ new policy - high energy efficiency $\times 450 \mathrm{ppm}$

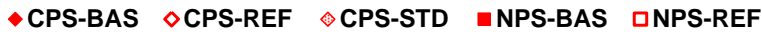

图NPS-STD $\triangle 450 S-B A S \triangle 450 S-R E F \quad \triangle 450 S-S T D$

- current legislation $\triangle$ advanced control measures

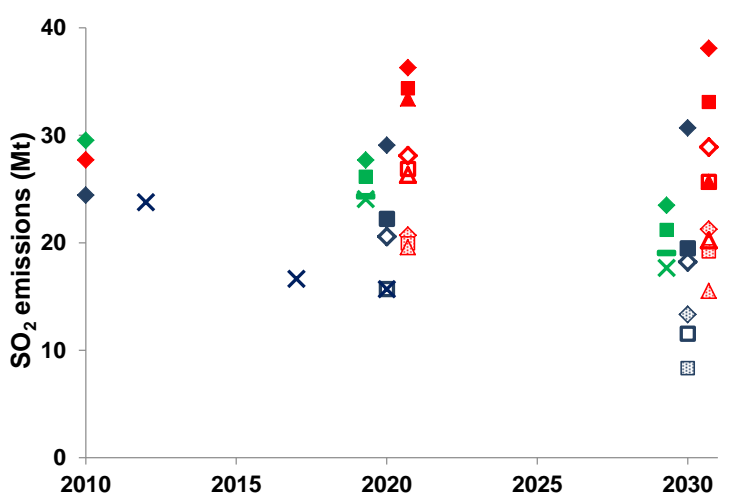

(b) $\mathrm{SO}_{2}$

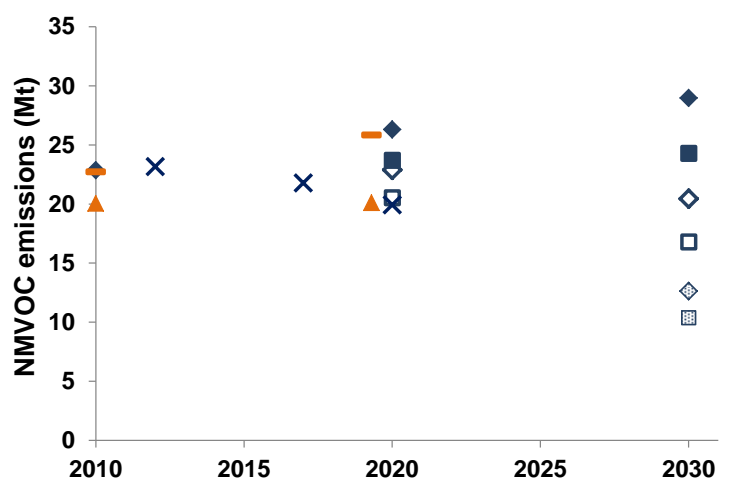

(d) NMVOC

1260 Figure 10 Projections of future emissions of major air pollutants in China up to 2030: (a) $\mathrm{NO}_{\mathrm{X}}$, (b) $\mathrm{SO}_{2}$, (c) $\mathrm{PM}_{2.5}$, (d) NMVOC. The scenarios developed by the same institute are shown with symbols of the same color, and since their historical emissions duplicate each other, we show just the historical values of one scenario. Some points for the years 2020 and 2030 are shifted a little left or right, in order to avoid overlapping representation. 